Supporting Information

\title{
Chemically Grafted Nanozyme Composite Cryogels to Enhance Antibacterial and Biocompatible Performance for Bioliquids Regulation and Adaptive Bacteria Trapping
}

Yanyan $\mathrm{Li}^{1}$, Dingqian Wang ${ }^{1}$, Jie Wen ${ }^{1}$, Peng $\mathrm{Yu}^{1}$, Jinming Liu ${ }^{1}$, Jianshu $\mathrm{Li}^{1,2 *}$, and

Hetao $\mathrm{Chu}^{1^{*}}$

${ }^{1}$ College of Polymer Science and Engineering, Sichuan University, Chengdu 610065, China

${ }^{2}$ State Key Laboratory of Polymer Materials Engineering, Sichuan University, Chengdu 610065, China

Keywords: interconnected macroporous structures, peroxidase and oxidase mimics, oxidative damage, biofluids management, adaptive bacteria capture 


\section{Materials}

Iron trichloride $\left(\mathrm{FeCl}_{3}\right)$ was purchased from Tianjin Damao Chemical Reagents Factory. Pluronic F127 (PF127, (poly (ethylene glycol)-b-poly (propylene glycol)-bpoly (ethylene glycol)) was obtained from Sigma-Aldrich. Chitosan (CS) was purchased from J\&K Scientific Ltd. (Mn = 100-300 kDa). Glycidyl methacrylate (GMA) was purchased from Aladdin. N, N-dimethylformamide (DMF) was purchased from Tianjin Fuchen Chemical Reagents Factory. Ammonium peroxodisulphate (APS) was purchased from Beijing Bailingwei Technology Co., Ltd. 2-aminoterephthalic acid ( $\mathrm{NH}_{2}$-BDC), acrylic chloride $\left(\mathrm{C}_{3} \mathrm{H}_{3} \mathrm{ClO}\right), 3,3$ ', 5, 5'-tetramethylbenzidine (TMB), and $\mathrm{N}, \mathrm{N}, \mathrm{N}^{\prime}, \mathrm{N}^{\prime}$-tetramethylethylenediamine (TEMED) were purchased from Shanghai Macklin Biochemical Co., Ltd. Sodium periodate $\left(\mathrm{NaIO}_{4}\right)$, aceticacid $\left(\mathrm{CH}_{3} \mathrm{CH}_{2} \mathrm{COOH}\right)$ and dichloromethane $\left(\mathrm{CH}_{2} \mathrm{Cl}_{2}\right)$ were purchased from Chengdu Kelong Chemical Co., Ltd. Sodium acetate anhydrous $\left(\mathrm{CH}_{3} \mathrm{CH}_{2} \mathrm{COONa}\right)$ and triethylamine $\left(\mathrm{C}_{6} \mathrm{H}_{15} \mathrm{~N}\right)$ was purchased from Tianjin Kermel Chemical Reagent Co., Ltd. Fetal bovine serum (FBS) was purchased from Gibco (South America). Dulbecco's modified eagle medium (DMEM) was purchased from Gibco (USA). Penicillin streptomycin solution, trypsin and phosphate buffer saline (PBS) were purchased from Hyclone (USA). Cell counting kit-8 (CCK-8), fluorescein isothiocyanate (FITC), and 4',6-diamidino-2-phenylindole (DAPI) were purchased from Solarbio (Beijing, China). Hoechst 33342 living cell staining solution was purchased from Beyotime (Shanghai, China). Interleukin-6 (IL6) was purchased from Beijing Bioss Biotechnology Co., Ltd. FITC conjugated goat anti-rabbit IgG was purchased from Servicebio. The water used in all experiments was 
deionized water (DI). All chemical reagents were used without further purification unless specified otherwise.

\section{Measurements and Characterizations}

\section{SEM Observation}

The SEM images of Fe-MIL-88 $\mathrm{NH}_{2}$ nanozyme were recorded on a JSM7500F (Hitachi, Japan) and Helios G4 UC (Thermo Fisher Scientific, Oxford). A small amount of Fe-MIL-88 $\mathrm{NH}_{2}$ nanozyme was ultrasonically dispersed into ethanol and then dropped onto the silicon chip. After the spin coating and drying, it was used for SEM observation.

The SEM morphology images and EDS analysis of nanozyme composite cryogel (CSG-Mx) samples were captured by Apreo S HiVoc (Thermo Fisher Scientific, USA). CSG-Mx samples were freeze-dried, and the section was cut out by blade for SEM observation and EDS analysis.

The SEM image of released Fe-MIL-88 $\mathrm{NH}_{2}$ nanozyme was recorded on a Apreo S HiVoc (Thermo Fisher Scientific, USA). CSG-M1.5 was soaked in solution with pH 3 for $1 \mathrm{~h}$ to obtain the extract. Then the extract was filtered with $800 \mu \mathrm{m}$ membrane and was appropriately concentrated by lyophilization. Next, the concentrated extract was dripped onto the surface of the silicon wafer using spin coater for SEM observation.

\section{TEM Observation}

The Tecnai G2 F20 S-TWIN TEM (Thermo Fisher Scientific, USA) was used to observe Fe-MIL-88NH 2 nanozyme. A small amount of Fe-MIL-88 $\mathrm{NH}_{2}$ nanozyme was ultrasonically dispersed into ethanol and then dropped onto the copper grid, and dried 
the sample at room temperature for TEM measurement.

\section{XRD Measurements}

The power XRD patterns of Fe-MIL-88 $\mathrm{NH}_{2}$ nanozyme, CS, CS-GMA, dialdehyde CS-GMA, and CSG-Mx were recorded on Ultima IV XRD diffractometer (Rigaku Corp, Japan) using $\mathrm{Cu} \mathrm{K \alpha}$ irradiation.

\section{Particle Size Measurements}

Hydrodynamic diameter of Fe-MIL- $88 \mathrm{NH}_{2}$ nanozyme was obtained by dynamic light scattering (Zetasizer $\mu \mathrm{V}$, Malvern, Japan). In this method, the used light source was $633 \mathrm{~nm}$ red lasers; the measurement angle was $90^{\circ}$; and each sample was measured 3 times for average.

\section{Zeta Potential Measurements}

Zeta potential of Fe-MIL-88 $\mathrm{NH}_{2}$ nanozyme, bacterial suspension, and CSG-Mx suspension was measured by Zetasizer Nano-ZS (Malvern, Japan). Samples were ultrasonically dispersed into acetic acid buffer solutions $(0.1 \mathrm{M})$ with different $\mathrm{pH}$ value to obtain suspension with concentration of $1 \mathrm{mg} / \mathrm{mL}$ for test. Each sample was measured 3 times for average.

\section{FTIR Measurements}

The Fe-MIL-88NH 2 nanozyme, CS, GMA-CS, dialdehyde CS-GMA, and CSGM1.5 after drying were performed FTIR testing. The FTIR spectra of samples were recorded on Nicolet is50 FTIR spectrometer (Thermo Fisher Corp, USA). The scanning range was from 400 to $4000 \mathrm{~nm}$.

\section{${ }^{1} \mathrm{H}$ NMR Tests}


The spectra of CS, CS-GMA, and dialdehyde CS-GMA were performed using a Bruker AV III HD $400 \mathrm{MHz}$ instrument with 95\% deuterium oxide and 5\% acetic-d3 acid-d serving as the solvents.

The spectrum of PF127-DA was performed using a Bruker AV III HD $400 \mathrm{MHz}$ instrument with chloroform-d serving as the solvents.

\section{The Actual Loading of Fe-MIL-88 $\mathrm{NH}_{2}$ in CSG-Mx}

The actual loading of Fe-MIL-88 $\mathrm{NH}_{2}$ in CSG-Mx was obtained by ICP-MS (VG PQExCell, Thermo Jarrell Ash, USA). The sheet samples of CSG-M1.0, CSG-M1.5, and CSG-M2.0 were soaked in EtOH for $24 \mathrm{~h}$ to purify and then dried. The dried samples were ground and boiled with concentrated nitric acid for 30 min to perform ICP-MS tests.

\section{EPR Tests}

The generation of active intermediates was confirmed by EPR (EMX Plus, Bruker Corp, Germany) spectrometer using DMPO spin-trapping adduct. ${ }^{1}$ The tests were carried out in acetic acid buffer solutions $(0.1 \mathrm{M}, \mathrm{pH} 4)$. And the concentration of FeMIL-88 $\mathrm{NH}_{2}$ nanozyme, $\mathrm{H}_{2} \mathrm{O}_{2}$, DMPO, CSG-M and CSG-M 1.5 was $50 \mu \mathrm{g} / \mathrm{mL}, 100 \mu \mathrm{M}$, $50 \mathrm{mM}, 1 \mathrm{mg} / \mathrm{mL}$, and $1 \mathrm{mg} / \mathrm{mL}$, respectively. After more than $10 \mathrm{~min}$, the reaction solutions were aspirated into quartz capillaries for EPR analysis.

\section{Mechanical Performance Tests}

The mechanical properties of CSG-Mx samples were measured using a HZ-1004B Tension Instrument with a $10 \mathrm{~N}$ load cell (Dongguan Lixian Science and Technology Ltd) at room temperature. CSG-Mx samples were fabricated into the cylinder with mold 
( $8 \mathrm{~mm}$ in diameter, $8 \mathrm{~mm}$ in height), which were used for static compression tests. And the compressive rate was $10 \mathrm{~mm} / \mathrm{min}$. Since the CSG-Mx samples would be used as wound dressings and need to be intact, the tests were terminated at $90 \%$ strain. For the cyclic compression tests, cylindrical CSG-Mx was compressed to a preset maximum strain and then returned to its initial length. The compressive rate was $10 \mathrm{~mm} / \mathrm{min}$ and each strain condition was tested cycle 3 times. After the first loading/unloading cycle, the CSG-Mx was not relaxed, and the loading/unloading cycle was conducted again immediately. At least 3 specimens were tested for each CSG-Mx sample to obtain the average values.

\section{Swelling Performance Tests}

CSG-Mx samples were lyophilized and firstly weighted $\left(W_{d}\right)$. Then they equilibrated in DI water at room temperature again weighted $\left(W_{w}\right)$. The swelling ratio $(S R)$ was calculated as:

$$
S R=\frac{W_{w}-W_{d}}{W_{d}} \times 100 \%
$$

For the swelling behavior of CSG-Mo and CSG-M 1.5 in simulated wound fluid with different $\mathrm{pH}, \mathrm{CSG}-\mathrm{M}_{0}$ and $\mathrm{CSG}-\mathrm{M}_{1.5}$ samples were lyophilized and firstly weighted $\left(W_{d}\right)$. Then they equilibrated in simulated wound fluid with different $\mathrm{pH}$ at room temperature again weighted $\left(W_{w}\right)$. The swelling ratio was calculated as above. The simulated wound fluid was prepared to use $2.22 \mathrm{~g}$ of $\mathrm{CaCl}_{2}, 23.38 \mathrm{~g}$ of $\mathrm{NaCl}$, and $20 \mathrm{~g}$ of BSA per $1 \mathrm{~L}$ of $\mathrm{NaAc}$ buffer $(0.1 \mathrm{M})$ with different $\mathrm{pH} .^{2}$ 


\section{Water Vapor Transmission Rate Tests}

We tested the water vapor transmission rate of CSG-Mx by referring to references with some modifies. ${ }^{3} 12 \mathrm{ml}$ of simulated wound fluid were added to a glass bottle with diameter of $2.5 \mathrm{~cm}$ and height of $4 \mathrm{~cm}$, and the bottle was sealed with CSG-Mx. Then put it in a constant temperature and humidity instrument (Temperature: $37^{\circ} \mathrm{C}$; Humidity: 30\%. Shanghai Yiheng Scientific Instrument Co., Ltd.). When steady-state conditions were reached (about $2 \mathrm{~h}$ ), seven weight measurements were made over $6 \mathrm{~h}$. The water vapor transmission rate was calculated according to the formula.

$$
W V T R=\frac{S \times d}{A \times \Delta P}
$$

Where $S$ is the slope of the weight loss versus time $\left(\mathrm{g} \mathrm{h}^{-1}\right), d$ is the thickness (m) of CSG-Mx, $A$ is the area of exposed CSG-Mx $\left(\mathrm{m}^{2}\right)$ and $\Delta P$ is the differential of water vapor pressure across the CSG-Mx (at $\left.37^{\circ} \mathrm{C}, \Delta P=6.26 \times 10^{3} \mathrm{~Pa}\right) .^{4-5}$

\section{Investigation of Biofluids Management}

The cuboid sample (width: $10 \mathrm{~mm}$; length: $35 \mathrm{~mm}$, thickness: $3 \mathrm{~mm}$ ) was mechanically extruded to remove free water, and then the bottom was immersed in solution containing rhodamine B or simulated wound fluid in which BSA was labeled by FITC. The ability of CSG-Mx to transport liquid in the opposite direction of gravity was recorded via digital camera under UV radiation $(\lambda=365 \mathrm{~nm})$.

In order to simulate the management of wound exudate by CSG-Mx, a simplified physical model was used. ${ }^{6}$ A syringe with a capacity of $1 \mathrm{~mL}$ was placed above or under 
the CSG-Mx samples and continuously supplied mixture solution of rhodamine B. The digital camera was used to visualize the absorption of mixture solution more clearly under UV radiation $(\lambda=360 \mathrm{~nm})$.

\section{Investigation of Hemostatic Properties}

The cylindrical CSG-M $\mathrm{M}_{\mathrm{x}}$ with a diameter of about $9 \mathrm{~mm}$ and a thickness of about $4 \mathrm{~mm}$ were drained off water and put into the test tube, then $50 \mu \mathrm{L}$ of whole-blood (containing EDTA) was dropped onto the CSG-Mx. Next, the test tube was incubated at $37^{\circ} \mathrm{C}$ for $30 \mathrm{~s}, 60 \mathrm{~s}, 90 \mathrm{~s}, 120 \mathrm{~s}$, and $150 \mathrm{~s}$, respectively. After the pre-set period, 10 $\mathrm{mL}$ of DI water was gently added to release unbound blood. After that, the optical density at $540 \mathrm{~nm}\left(\mathrm{OD}_{540} \mathrm{~nm}\right)$ was detected. The absorbance of $50 \mu \mathrm{L}$ of whole-blood in $10 \mathrm{~mL}$ DI water was used as the control. The blood-clotting index $(B C I)$ was calculated using equation:

$$
B C I(\%)=\frac{I s-I o}{I r-I o} \times 100 \%
$$

Where Is represented the absorbance of sample, Io represented the absorbance of blank well plates, and $\operatorname{Ir}$ represented the absorbance of control. ${ }^{7}$

The CSG-Mx incubated with whole-blood (containing EDTA) was washed 4 times with a large amount of PBS, and then fixed with $2.5 \%$ glutaraldehyde for $2 \mathrm{~h}$. After that, blood cells in the samples gradually dehydrated using $50 \%, 60 \%, 70 \%, 80 \%, 90 \%$, and $100 \%$ ethanol solution with time interval of $10 \mathrm{~min}$. The lyophilizate samples were observed using SEM. ${ }^{7}$ 


\section{Peroxidase and Oxidase Mimicry Activity and Kinetics Assay}

According to references ${ }^{8}$ typical TMB color reactions were performed to systematically evaluate the peroxidase and oxidase mimicry activities of Fe-MIL$88 \mathrm{NH}_{2}$ and CSG-Mx. All kinetic measurements were obtained in a time-scan mode at $652 \mathrm{~nm}$ by PERSEE TU-1901 UV spectrophotometer. Under the conditions of room temperature and $\mathrm{pH} 4(0.1 \mathrm{M} \mathrm{NaAc}$ buffer $)$, the reaction was carried out for $60 \mathrm{~s}$ for steady-state kinetic analysis. To check the ability of Fe-MIL- $88 \mathrm{NH}_{2}$ and CSG-Mx as catalyst for the oxidizing of TMB, the measurement was performed in a spectral scan mode by monitoring the absorbance change in the range of $360-750 \mathrm{~nm}$ after reaction $15 \mathrm{~min}$. The concentration of Fe-MIL-88 $\mathrm{NH}_{2}$ and CSG-Mx was $50 \mu \mathrm{g} / \mathrm{mL}$ and $1 \mathrm{mg} / \mathrm{mL}$. For the peroxidase mimic activities of Fe-MIL- $88 \mathrm{NH}_{2}$, the concentration of $\mathrm{H}_{2} \mathrm{O}_{2}$ was $0.5 \mathrm{mM}$. For the peroxidase mimic activities of CSG-Mx, the concentration of $\mathrm{H}_{2} \mathrm{O}_{2}$ was $100 \mu \mathrm{M}$. The same conditions were used to test the dependence of the catalytic ability on $\mathrm{pH}$ and temperature through monitoring the absorbance change at $652 \mathrm{~nm}$ after reaction $15 \mathrm{~min}$.

For kinetic parameters, the experiments were carried out in $0.1 \mathrm{M} \mathrm{NaAc}$ buffer containing $50 \mu \mathrm{g} / \mathrm{mL}$ of Fe-MIL- $88 \mathrm{NH}_{2}, 1 \mathrm{mM}$ TMB, and a series of concentrations of $\mathrm{H}_{2} \mathrm{O}_{2}$ ranging from 0 to $0.5 \mathrm{mM}$, or containing $50 \mu \mathrm{g} / \mathrm{mL}$ of Fe-MIL- $88 \mathrm{NH}_{2}, 0.05 \mathrm{mM}$ $\mathrm{H}_{2} \mathrm{O}_{2}$, and a series of concentrations of TMB ranging from 0 to $1 \mathrm{mM}$. All experiments were repeated three times. The Michaelis-Menten constant was calculated according to: ${ }^{9}$

$$
\frac{1}{V}=\frac{\mathrm{K}_{M}}{V_{\max }[S]}+\frac{1}{V_{\max }}
$$


Where $V$ represents the initial velocity, $K_{\mathrm{M}}$ represents the Michaelis constant, $[S]$ is the concentration of substrate, and $V_{\max }$ is the maximal reaction velocity.

For testing the effect of time on the catalytic reaction of Fe-MIL- $88 \mathrm{NH}_{2}$ and CSGM1.5, PERSEE TU-1901 UV spectrophotometer was used in a time-scan mode to record the absorbance of $652 \mathrm{~nm}$. The experiments were carried out in $0.1 \mathrm{M} \mathrm{NaAc}$ buffer containing $100 \mu \mathrm{M} \mathrm{H}_{2} \mathrm{O}_{2}, 1 \mathrm{mM}$ TMB, and $50 \mu \mathrm{g} / \mathrm{mL}$ of Fe-MIL-88NH 2 or $1 \mathrm{mg} / \mathrm{mL}$ of CSG-M1.5.

\section{Trapping Bacteria under Different pH}

The monocolony of $S$. aureus on solid Luria-Bertani (LB) agar plates was transferred to $14 \mathrm{ml}$ of liquid LB culture medium and incubated in shaking table (180 rpm) at $37^{\circ} \mathrm{C}$ for $12 \mathrm{~h}$. Then the bacteria solution was diluted 3 times by NaAc buffer with different $\mathrm{pH}$ for the bacteria capture experiment. The cylindrical CSG-M1.5 with a diameter of about $9 \mathrm{~mm}$ and a thickness of about $8 \mathrm{~mm}$ after draining off water was put into the test tube, and $1.5 \mathrm{~mL}$ of bacterial solution was added, then the test tube was placed in the refrigerator at $4{ }^{\circ} \mathrm{C}$ for $1 \mathrm{~h}$ to trap bacteria. After that, removing the CSG$\mathrm{M}_{1.5}$, the bacterial concentration was detected by measuring the optical density at 600 $\mathrm{nm}\left(\mathrm{OD}_{600} \mathrm{~nm}\right)$.

Furthermore, the CSG-M1.5 samples removed from the bacterial solution were immersed in $2.5 \%$ glutaraldehyde for $4 \mathrm{~h}$. After that, $S$. aureus in the samples gradually dehydrated using $30 \%, 50 \%, 70 \%, 85 \%, 95 \%$, and $100 \%$ ethanol solution with time interval of $15 \mathrm{~min}$. Then, CSG-M 1.5 samples were freeze-dried for $24 \mathrm{~h}$. The 
lyophilization samples were observed by SEM (Hitachi 8010). ${ }^{10}$

\section{Antibacterial Experiments}

The monocolony of $S$. aureus or E. coli on solid Luria-Bertani (LB) agar plates was transferred to $14 \mathrm{ml}$ of liquid LB culture medium and incubated in shaking table (180 rpm) at $37^{\circ} \mathrm{C}$ for $12 \mathrm{~h}$. The absorbance value of bacterial suspension at $600 \mathrm{~nm}$ was measured by microplate reader to estimate the number of bacteria. The bacteria solution was diluted by NaAc buffer $(0.1 \mathrm{M})$ with different $\mathrm{pH}$ to $10^{6} \mathrm{CFU} / \mathrm{mL}$ to obtain the bacterial solution with $\mathrm{pH} 7,6,5,4$, and 3 respectively. In the presence or absence of $\mathrm{H}_{2} \mathrm{O}_{2}(100 \mu \mathrm{M}), 300 \mu \mathrm{L}$ bacteria solution $\left(10^{6} \mathrm{CFU} / \mathrm{mL}\right)$ was co-cultured with cryogel samples (cylinder with diameter of $9 \mathrm{~mm}$ and thickness of $4 \mathrm{~mm}$ ) including CSG-M0, CSG/M1.5, and CSG-M 1.5 for $1 \mathrm{~h}$ at room temperature (40 groups in total). Subsequently, the bacterial solution after contacting with the cryogel sample was diluted $10^{4}$ times, and $100 \mu \mathrm{L}$ of bacterial solution were applied to the solid medium for the spread plate. The plates were incubated in $37{ }^{\circ} \mathrm{C}$ oven for $9-12 \mathrm{~h}$, and recorded the number of colonies forming units (CFU).

\section{Acid Response Dynamic Release and Rebinding of Fe-MIL-88NH}

Fe-MIL-88 $\mathrm{NH}_{2}$ was grafted to cryogel through Schiff base reaction. The dynamic release and rebinding of Fe-MIL- $88 \mathrm{NH}_{2}$ under different $\mathrm{pH}$ was obtained by ICP-MS (VG PQExCell, Thermo Jarrell Ash, USA). The cylindrical CSG-M1.5 with a diameter of about $9 \mathrm{~mm}$ and a thickness of about $8 \mathrm{~mm}$ was put into the test tube, and $4 \mathrm{~mL}$ of NaAc buffer $(0.1 \mathrm{M})$ with different $\mathrm{pH}(7,6,5,4$, and 3) was added respectively, then placed at room temperature for $1 \mathrm{~h}$. The extract was filtered with $800 \mu \mathrm{m}$ membrane 
and boiled with concentrated nitric acid for $30 \mathrm{~min}$ to perform ICP-MS tests. To verify whether the Fe-MIL-88 $\mathrm{NH}_{2}$ released under acidic conditions rebind to cryogel when the $\mathrm{pH}$ returns to neutral, CSG-M1.5 in the test tube was soaked in the NaAc buffer (only performed in $\mathrm{pH} 3,4$, or 5) for $1 \mathrm{~h}$, then adjusted to $\mathrm{pH} 7$ and placed for another $1 \mathrm{~h}$. After that, the extract was filtered with $800 \mu \mathrm{m}$ membrane and boiled with concentrated nitric acid for 30 min to perform ICP-MS tests.

\section{Cytotoxicity Assessment}

The mouse L929 subclone cell line purchased from Shanghai Zhong Qiao Xin Zhou Biotechnology Co., Ltd. were cultured in DMEM medium containing 10\% fetal bovine serum (FBS, Gibco, South America), $100 \mu \mathrm{M}$ penicillin and $100 \mu \mathrm{g} / \mathrm{mL}$ streptomycin at $37{ }^{\circ} \mathrm{C}$ in $5 \% \mathrm{CO}_{2}$ incubator (MCO-15AC, Sanyo, Japan). L929 cells were seeded in 48 well plates with an initial cell density of $1.5 \times 10^{4}$ cells/well and incubated for $24 \mathrm{~h}$. Then, CSG-Mx sheets with a diameter of $9 \mathrm{~mm}$ and a thickness of $4 \mathrm{~mm}$ were incubated with the cells for $24 \mathrm{~h}$ or $48 \mathrm{~h}$. CCK-8 assay kit was used to quantify cell viability.

\section{Cell Migration}

The in vitro cell migration assay was performed to estimate the effect of Fe-MIL$88 \mathrm{NH}_{2}$ nanozymes and CSG-Mx on cell behavior. ${ }^{10}$ L929 cells were used for scratch assays. To facilitate observation, a working liquid of Hoechst 33342 living cell fluorochrome (Beyotime) was used to dye the cells with $10 \mathrm{~min}$ at room temperature. Cells were seeded in 24 well plates with an initial cell density of $2 \times 10^{5}$ cells/well and incubated for $24 \mathrm{~h}$. Then, a linear wound was made by scratching with a pipette tip. 
Cells were washed twice with PBS solution and visualized via fluorescence microscope (Olympus IX71, Japan). After that, fresh DMEM was added and Fe-MIL-88NH nanozymes $(50 \mu \mathrm{g} / \mathrm{mL})$ or CSG-Mx sheets with a diameter of $9 \mathrm{~mm}$ and a thickness of $4 \mathrm{~mm}$ were incubated with the cells for $24 \mathrm{~h}$. Cells were visualized again via fluorescence microscope.

\section{In Vivo Modeling and Wound Healing Process}

Healthy male Kunming mice (30-40 g) were purchased from Chengdu dossy experimental animal Co., Ltd. And the animal experiments were carried out with the permission of the Animal Research Committee (Sichuan University, Chengdu, China).

A round full-thickness cutaneous wound on the back of mice was used to investigate the effect of the composite cryogel samples on wound healing. The mice were acclimatized $3 \mathrm{~d}$ before surgery. The mice were shaved on their backs and then anesthetized, and two full-thickness cutaneous wounds with a diameter of about $7 \mathrm{~mm}$ were created on the back. After that, $10 \mu \mathrm{L}$ of $S$. aureus solution $\left(10^{8} \mathrm{CFU} / \mathrm{mL}\right)$ was dripped onto the wound for infection. The mice after adding $S$. aureus solution were divided into 16 groups (each group contained 3 mice) to perform different treatment: (1) control, CSG-M0, CSG/M1.5, CSG-M1.5 without $\mathrm{H}_{2} \mathrm{O}_{2}$; (2) control, CSG-M0, CSG/M1.5, CSG-M1.5 with $100 \mu \mathrm{M} \mathrm{H}_{2} \mathrm{O}_{2}$; (3) control, CSG-Mo, CSG/M1.5, CSG-M 1.5 without $\mathrm{H}_{2} \mathrm{O}_{2}$ and at pH4; (4) control, CSG-Mo, CSG/M1.5, CSG-M 1.5 with $100 \mu \mathrm{M}$ $\mathrm{H}_{2} \mathrm{O}_{2}$ and at $\mathrm{pH} 4$. The materials applied to the wound were squeezed to remove most of the water. Tegaderm ${ }^{3 \mathrm{M}}$ films were used to make the healing through reepithelialization and granulation, better simulating the healing response of humans. The 
wound was created on day 0 , and was measured by a digital caliper and photographed at day $0,3,6,8$, and 10 to observe the wound healing process. The CSG-Mx samples were replaced while photographing the wound.

\section{Histological Analysis}

On the 10th day, the mice were sacrificed. The related wound tissues and organs (heart, liver, spleen, lung, kidney) were harvested and fixed in $4 \%$ formaldehyde, and then embedded in paraffin. The samples were cross sectioned into slices, and fixed on a glass slide with hematoxylin-eosin (H\&E) staining for histological analysis. ${ }^{11}$ Then, stained samples were observed on an Olympus IX-71 optical system.

\section{Immunofluorescence Analysis}

Immunofluorescence experiments were performed according to reference with some modified. Paraffin tissues slices were deparaffinized, and washed three times by PBS for $5 \mathrm{~min}$, then blocked and permeabilized with newborn bovine serum (5\%) and $0.5 \%$ Triton $\mathrm{X}-100$ for $0.5 \mathrm{~h}$. Next, tissues slices were incubated with primary antibodies overnight at $4^{\circ} \mathrm{C}$. After washing three times by PBS, the slices were incubated in the blocking buffer containing corresponding fluorophore-conjugated secondary antibodies for $0.5 \mathrm{~h}$ at $37^{\circ} \mathrm{C}$. Tissues slices were washed three times with PBS again, then stained with DAPI and incubated with antifade solution to reduce autofluorescence using for immunofluorescence images. The following primary antibodies were used: IL-6 (1:100) from Beijing Bioss Biotechnology Co., Ltd. FITC conjugated goat anti-rabbit IgG from Servicebio was used at 1:100 dilutions. ${ }^{11}$ 


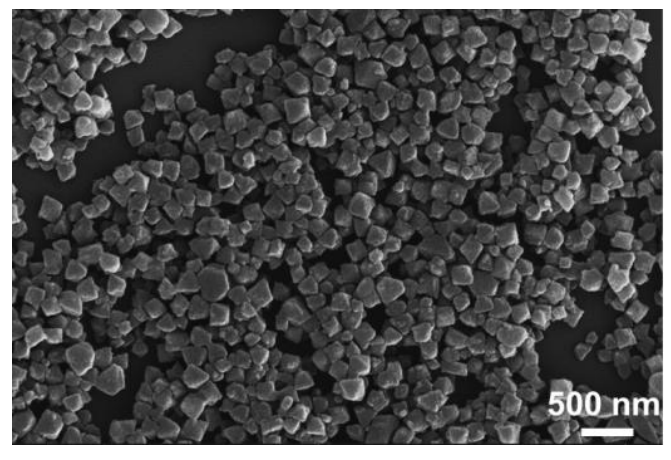

Figure S1. SEM image of Fe-MIL-88NH2.
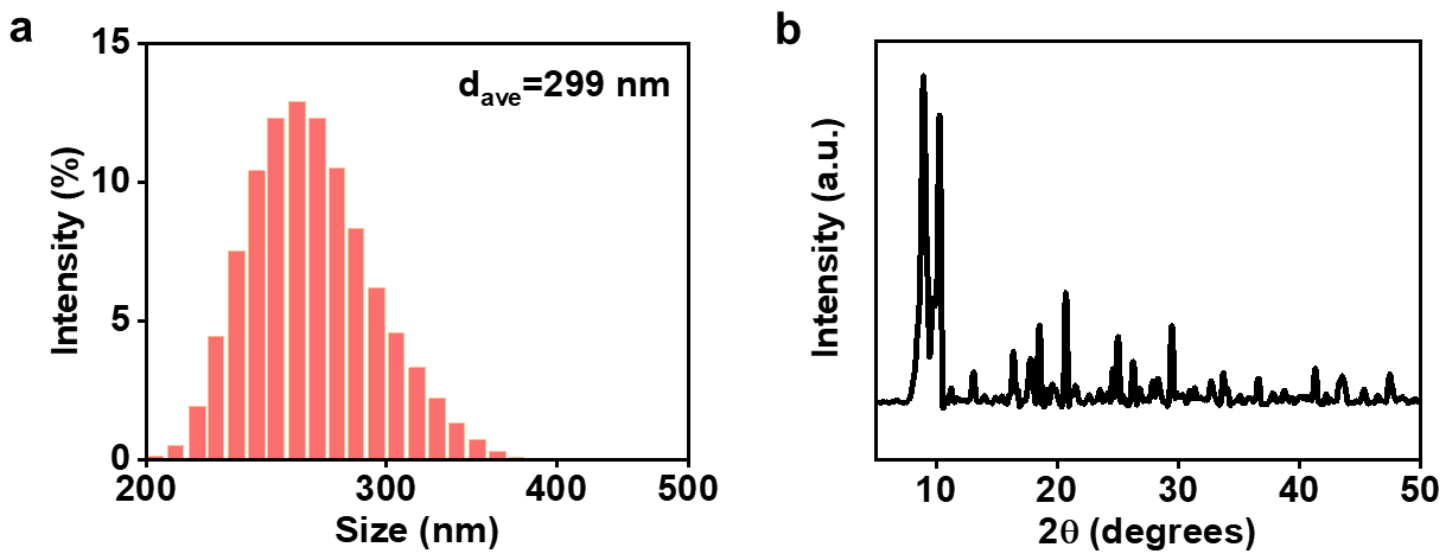

Figure S2. a) Particle size distribution histogram in deionized water and b) XRD pattern of Fe-MIL-88 $\mathrm{NH}_{2}$ nanozyme. 
a

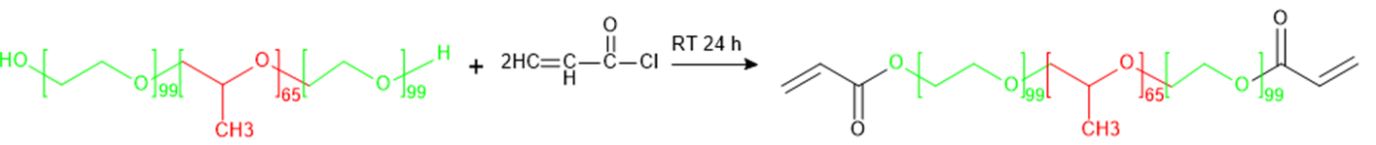

PF127

PF127-DA

b

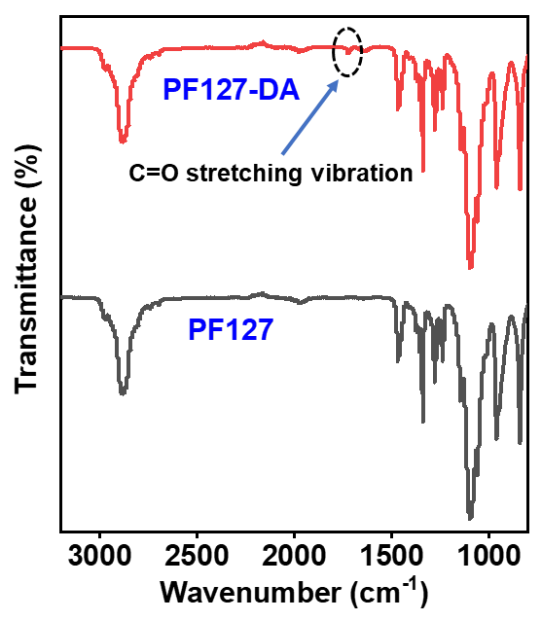

Figure S3. a) Synthesis route of PF127-DA and b) FTIR spectra of PF127-DA and PF127.

A new characteristic absorption peak of $\mathrm{C}=\mathrm{O}$ stretching vibration at $1722 \mathrm{~cm}^{-1}$ in PF127-DA from acryloyl. ${ }^{7,12}$

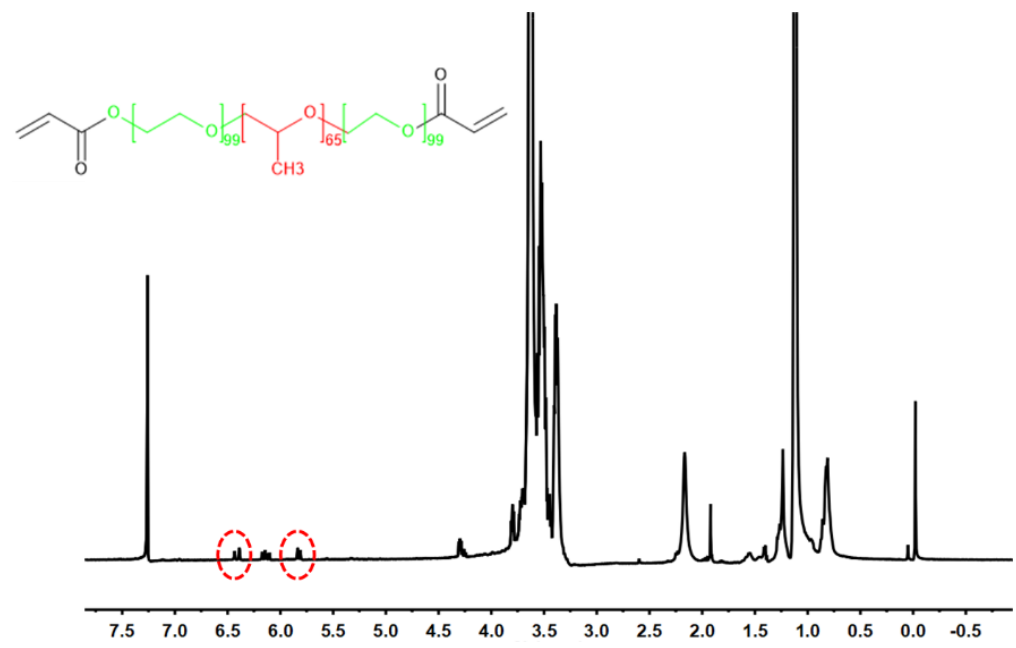

Figure S4. ${ }^{1}$ H NMR spectrum of PF127-DA.

Two chemical shifts at 5.9 and $6.4 \mathrm{ppm}$ attributed to the double bonds of acrylate 
demonstrated the successful acylation of PF127. ${ }^{12-13}$

a

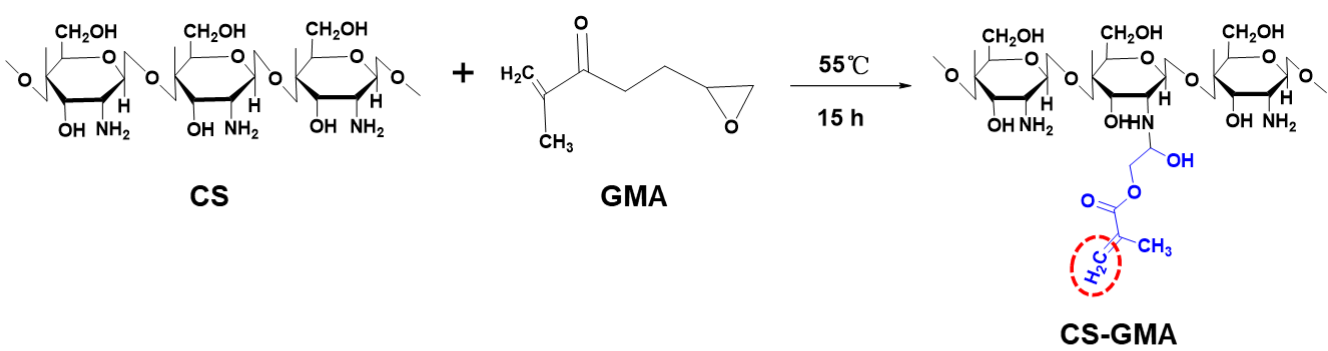

b

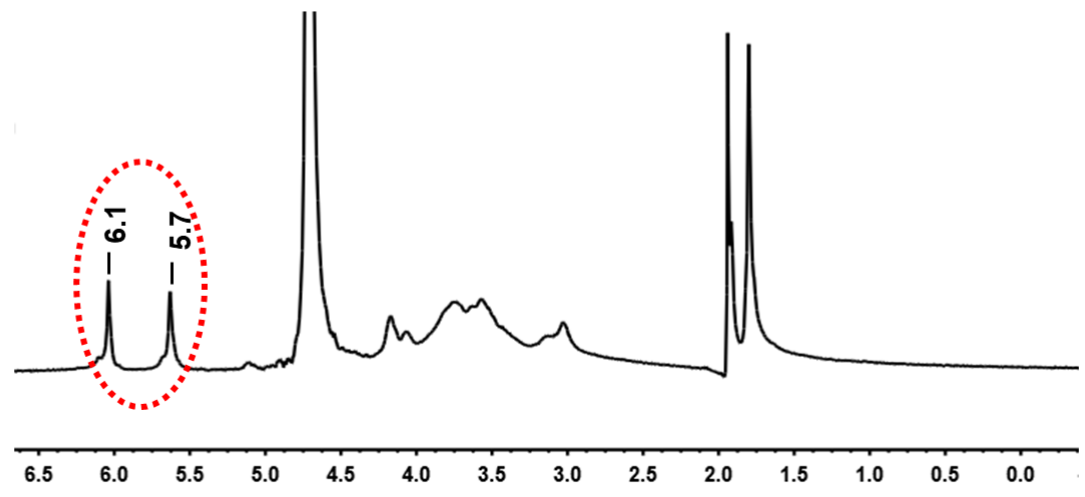

Figure S5. a) Synthesis route and b) ${ }^{1} \mathrm{H}$ NMR spectrum of CS-GMA.

Two chemical shifts at 5.7 and $6.1 \mathrm{ppm}$ assigned to double bonds from GMA demonstrated the successful synthesis of CS-GMA. ${ }^{7}$ 
a

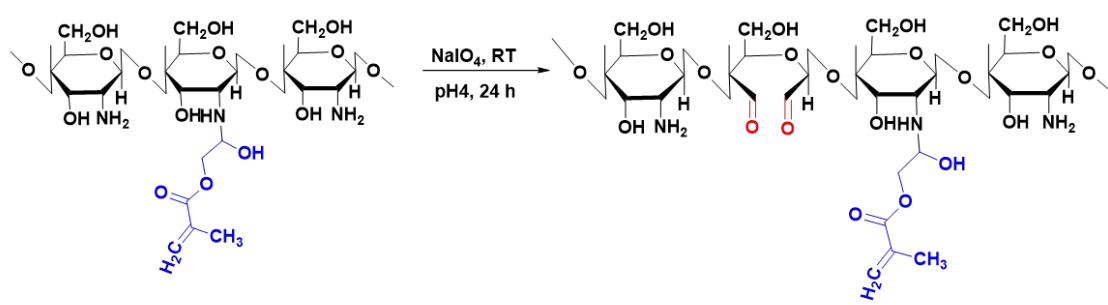

CS-GMA

Oxidized CS-GMA

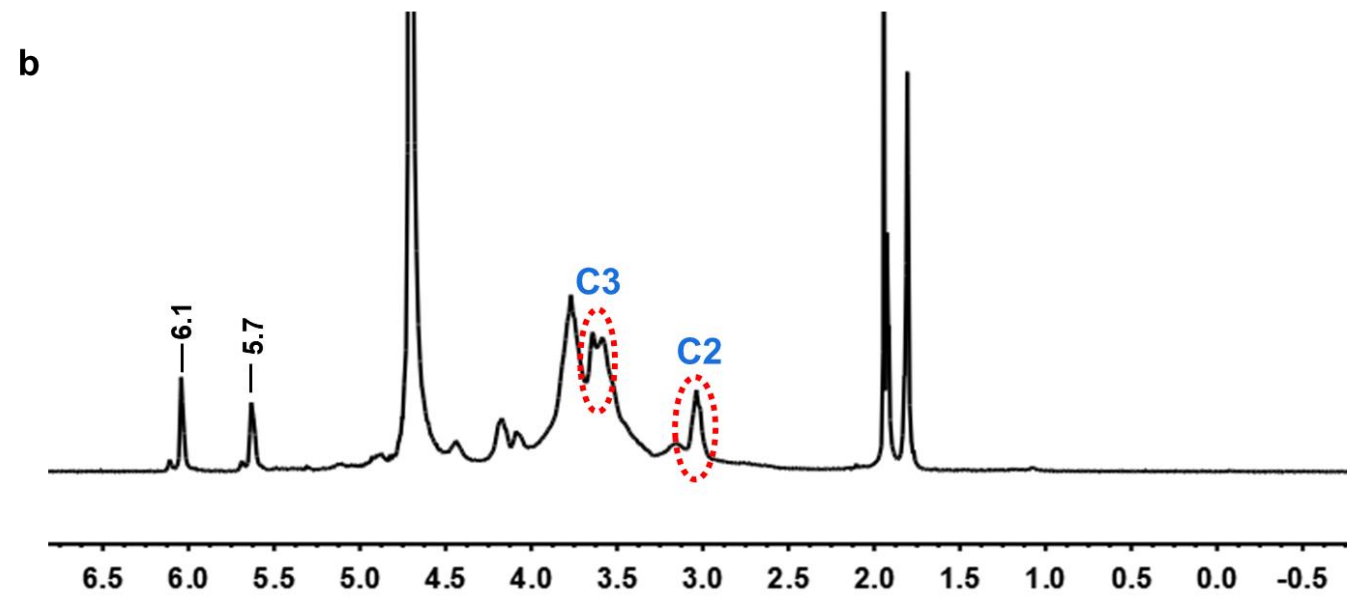

Figure S6. a) Synthesis route and b) ${ }^{1} \mathrm{H}$ NMR spectrum of dialdehyde CS-GMA.
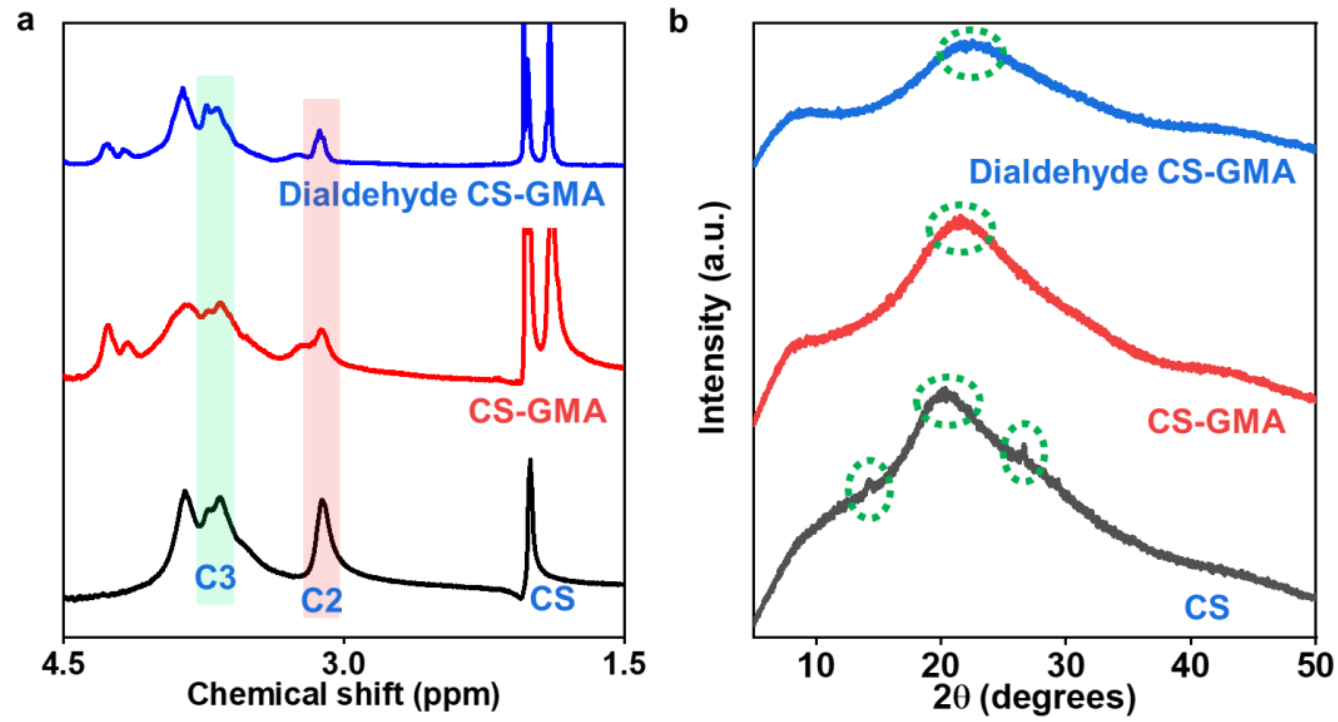

Figure S7. a) ${ }^{1} \mathrm{H}$ NMR spectra and b) XRD spectra of dialdehyde CS-GMA, CS-

GMA and CS. 
The characteristic chemical shifts at 3.6 and $3.1 \mathrm{ppm}$ related to the $\mathrm{C} 3$ and $\mathrm{C} 2$ of CS are significantly changed. The results indicate that the oxidation occurs at the C3 and $\mathrm{C} 2$ positions. ${ }^{14}$

a

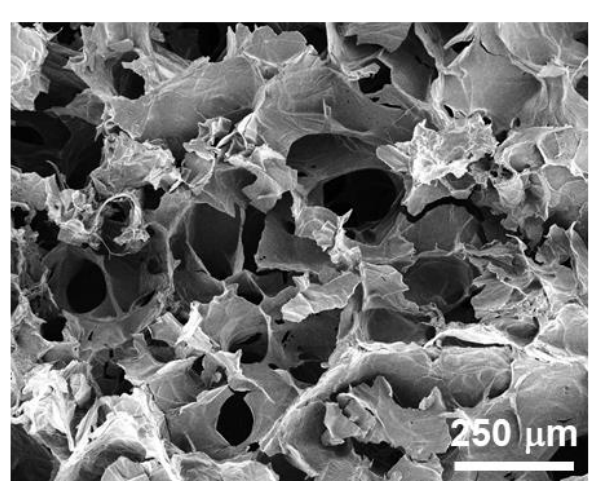

b

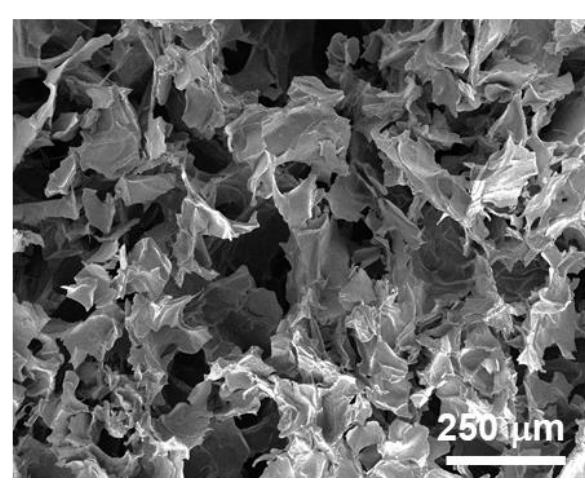

Figure S8. SEM morphology images of a) CSG-M1.0 and b) CSG-M2.0.

a

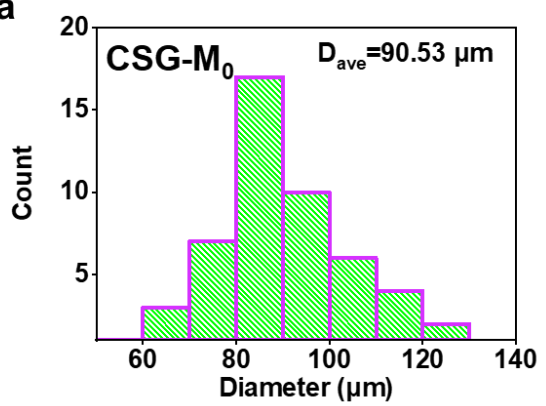

C

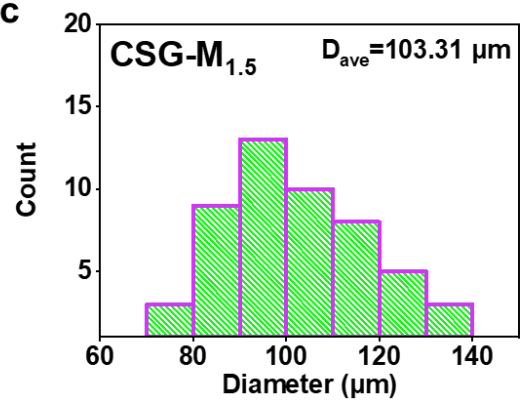

b
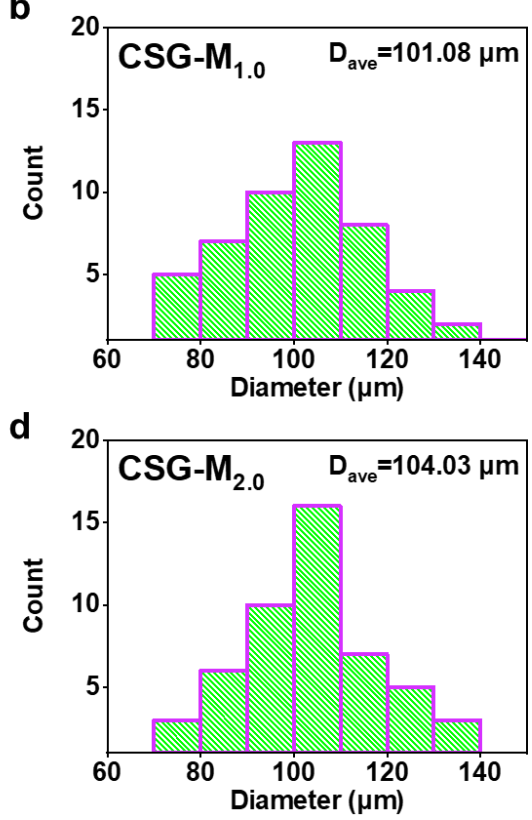

Figure S9. The size distributions for the pore of CSG-Mo, CSG-M 1.0, CSG-M1.5, 

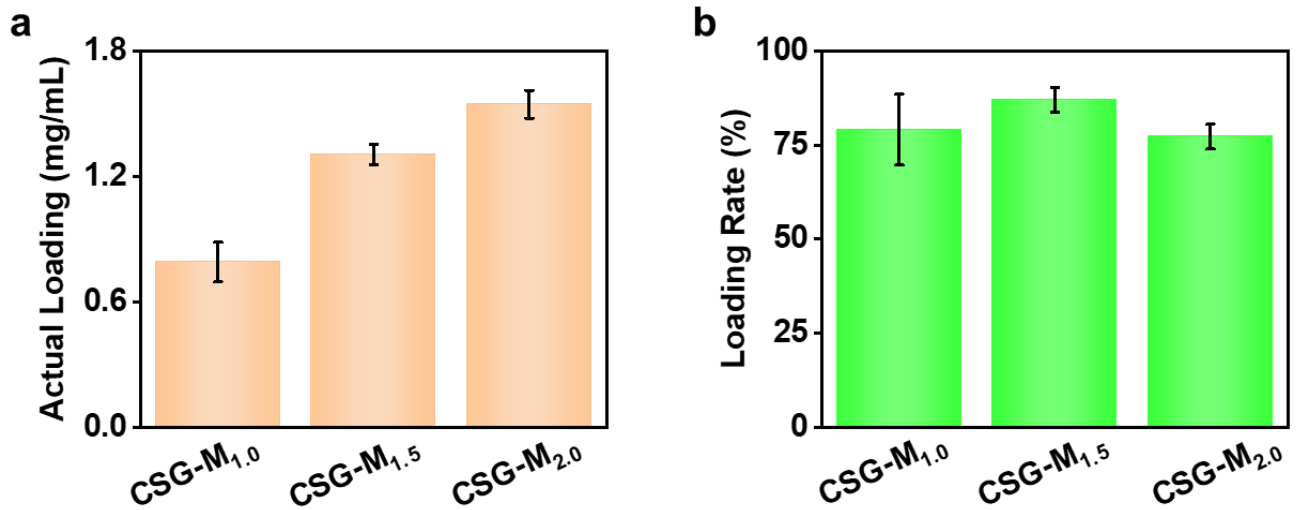

Figure S10. ICP-MS demonstrating the actual loading of Fe-MIL-88 $\mathrm{NH}_{2}$ in CSG-

$$
\text { M1.0, CSG-M1.5, and CSG-M2.0. }
$$

a

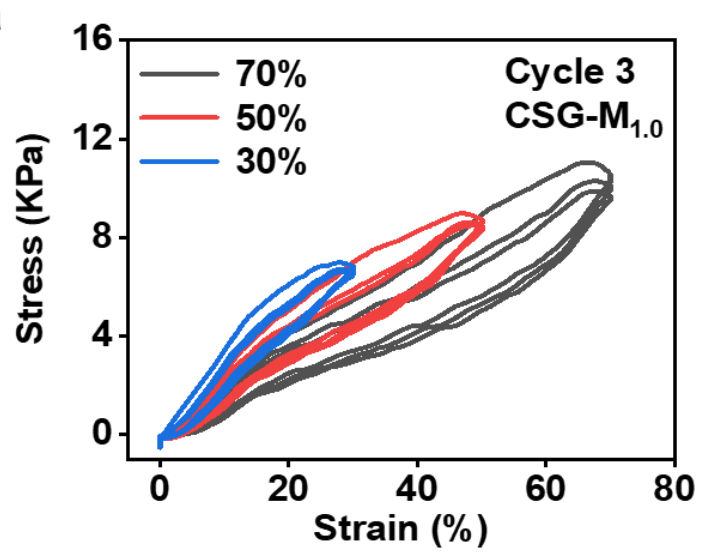

b

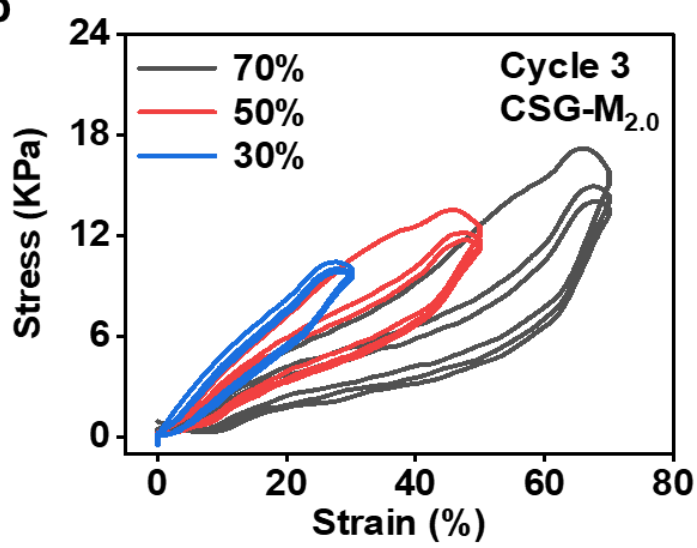

Figure S11. Three consecutive loading-unloading compression cycles of a) CSG-M1.0 and b) CSG-M2.0 under different strain.
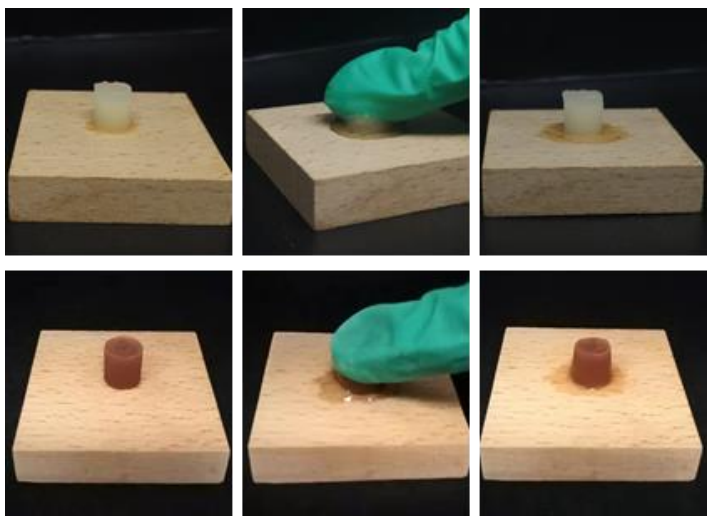

Figure S12. Loading-unloading compression images of CSG-M $\mathrm{M}_{0}$ and CSG-M1.5. 

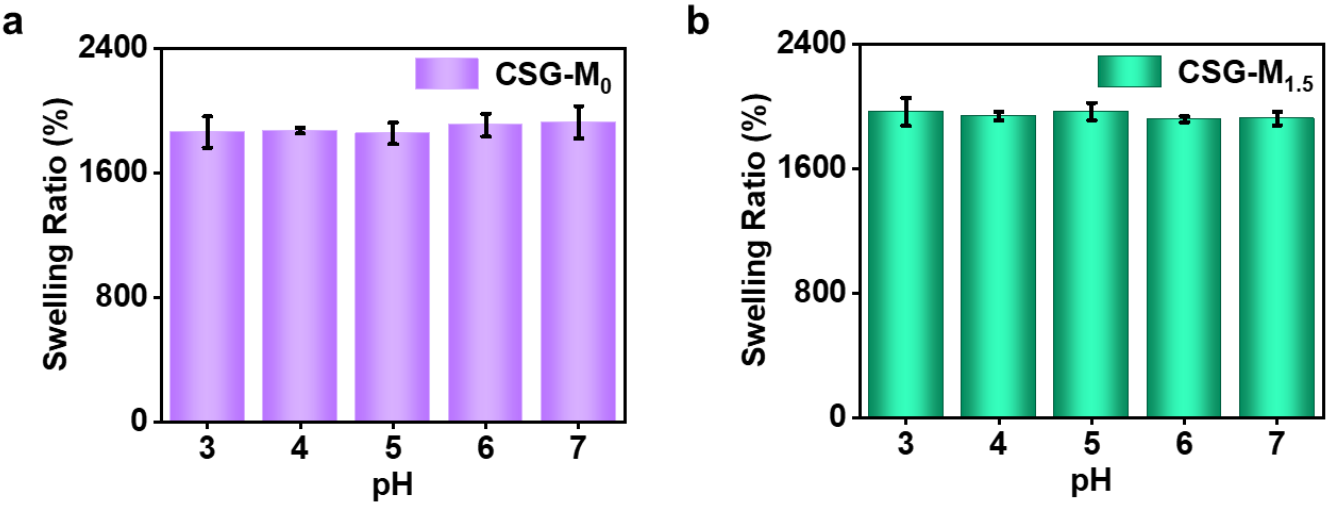

Figure S13. The swelling behaviors of a) CSG-M0 and b) CSG-M1.5 at different $\mathrm{pH}$ in simulated wound fluid.

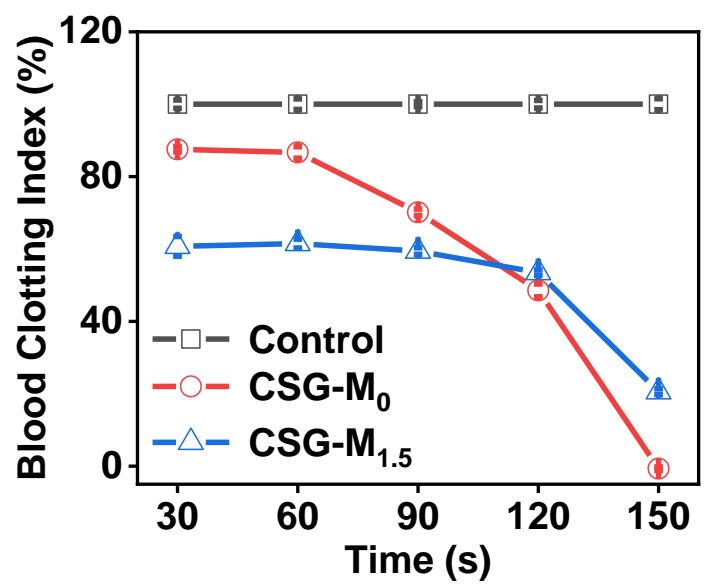

Figure S14. The dynamic whole-blood-clotting evaluation of the CSG-Mo and CSG$\mathrm{M}_{1.5}$. 
a
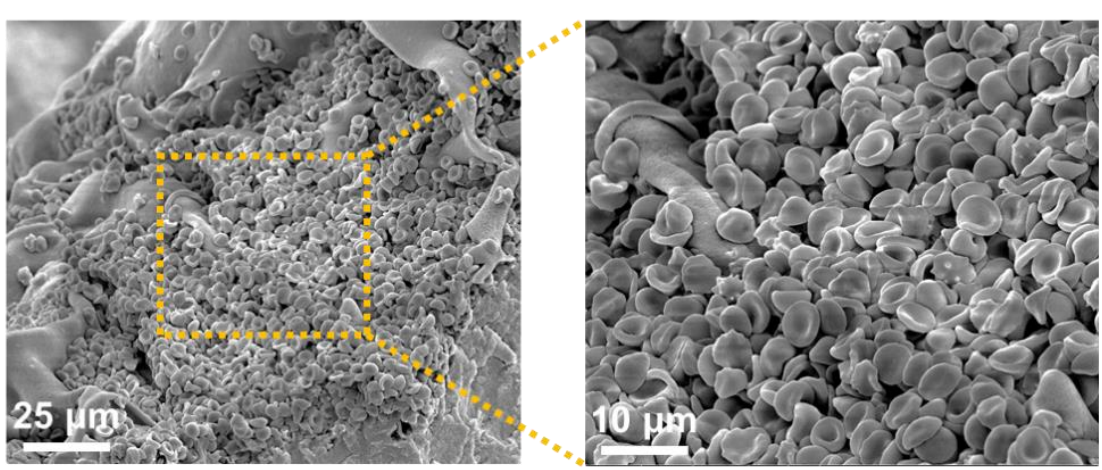

b
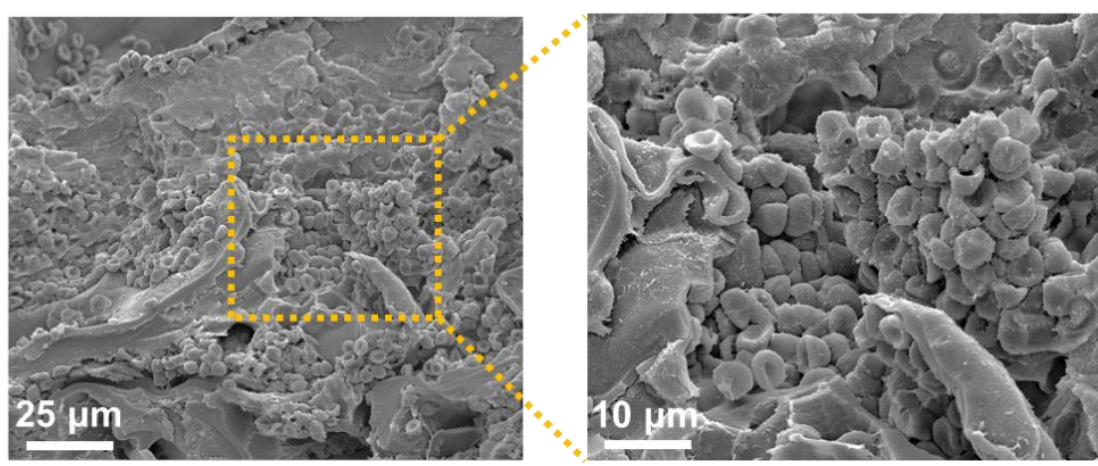

Figure S15. SEM images of hemocyte adhesion on the CSG-M0 and CSG-M1.5.

a<smiles>COc1cc(-c2cc(O)c(N)c(OC)c2)cc([14CH3])c1N</smiles>

TMB<smiles>COC1=CC(=C2C=C(Cl)C(=N)C(OC)=C2)C=C(O)C1=N</smiles>

OX-TMB
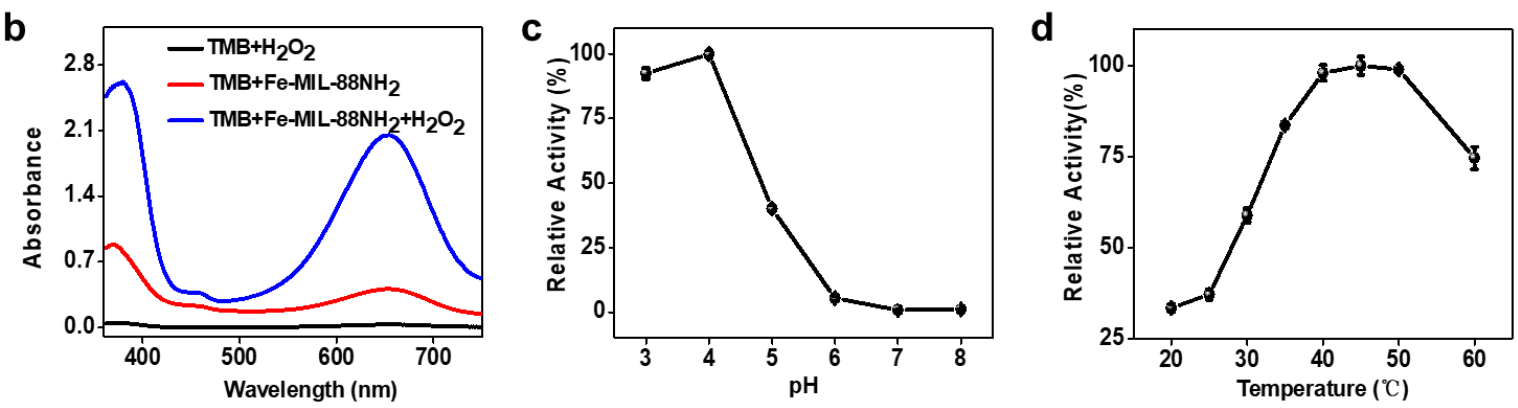

Figure S16. a) Schematic representation of Fe-MIL- $88 \mathrm{NH}_{2}$ catalytic oxidation TMB

color reaction. ${ }^{15}$ b) UV-vis absorption spectra of different system. The dependence of the peroxidase-like catalytic activity of Fe-MIL- $88 \mathrm{NH}_{2}$ on c) $\mathrm{pH}$ and d) temperature. 
All tests were carried out after 15 min of reaction. And the maximum point in each curve was set as 100\% (TMB: $1 \mathrm{mM}$; Fe-MIL-88NH $2: 50 \mu \mathrm{g} / \mathrm{mL} ; \mathrm{H}_{2} \mathrm{O}_{2}: 0.5 \mathrm{mM} ; 0.1$ M NaAc buffer).
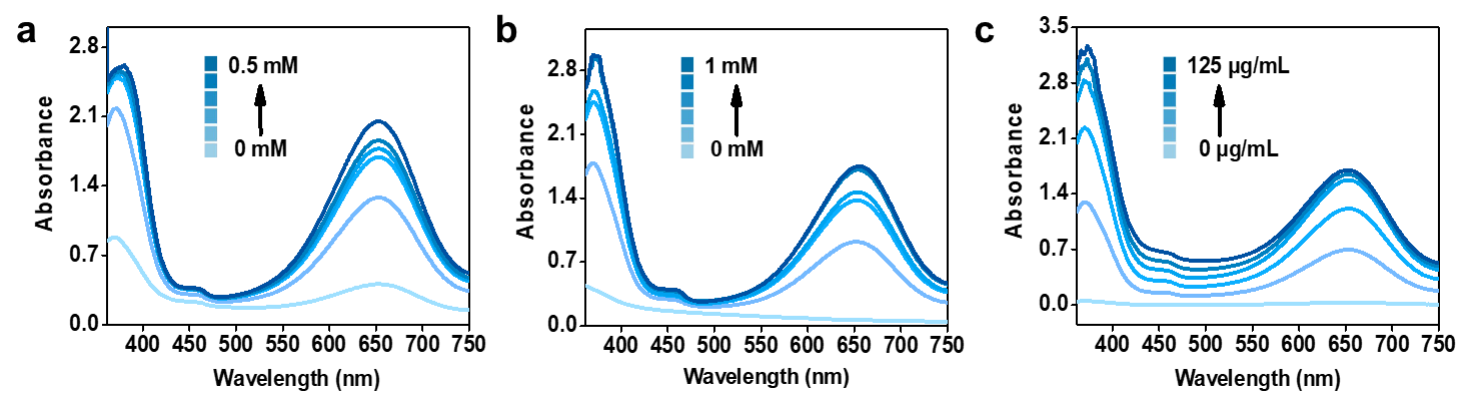

Figure S17. The dependence of the peroxidase-like catalytic activity of Fe-MIL$88 \mathrm{NH}_{2}$ on concentration of a) $\mathrm{H}_{2} \mathrm{O}_{2}$, b) TMB, and d) Fe-MIL- $88 \mathrm{NH}_{2}$.

The experiments were carried out in $0.1 \mathrm{M} \mathrm{NaAc}$ buffer containing $50 \mu \mathrm{g} / \mathrm{mL}$ of Fe-MIL-88NH $2,1 \mathrm{mM}$ TMB, and a series of concentrations of $\mathrm{H}_{2} \mathrm{O}_{2}$ ranging from 0 to $0.5 \mathrm{mM}$, or containing $50 \mu \mathrm{g} / \mathrm{mL}$ of Fe-MIL- $88 \mathrm{NH}_{2}, 0.05 \mathrm{mM} \mathrm{H}_{2} \mathrm{O}_{2}$, and a series of concentrations of TMB ranging from 0 to $1 \mathrm{mM}$, or containing $0.05 \mathrm{mM}$ of $\mathrm{H}_{2} \mathrm{O}_{2}, 1$ $\mathrm{mM} \mathrm{TMB}$, and a series of concentrations of Fe-MIL-88 $\mathrm{NH}_{2}$ ranging from 0 to 125 $\mu \mathrm{g} / \mathrm{mL}$. All tests were carried out after $15 \mathrm{~min}$ of reaction under $\mathrm{pH} 4$ and room temperature. 

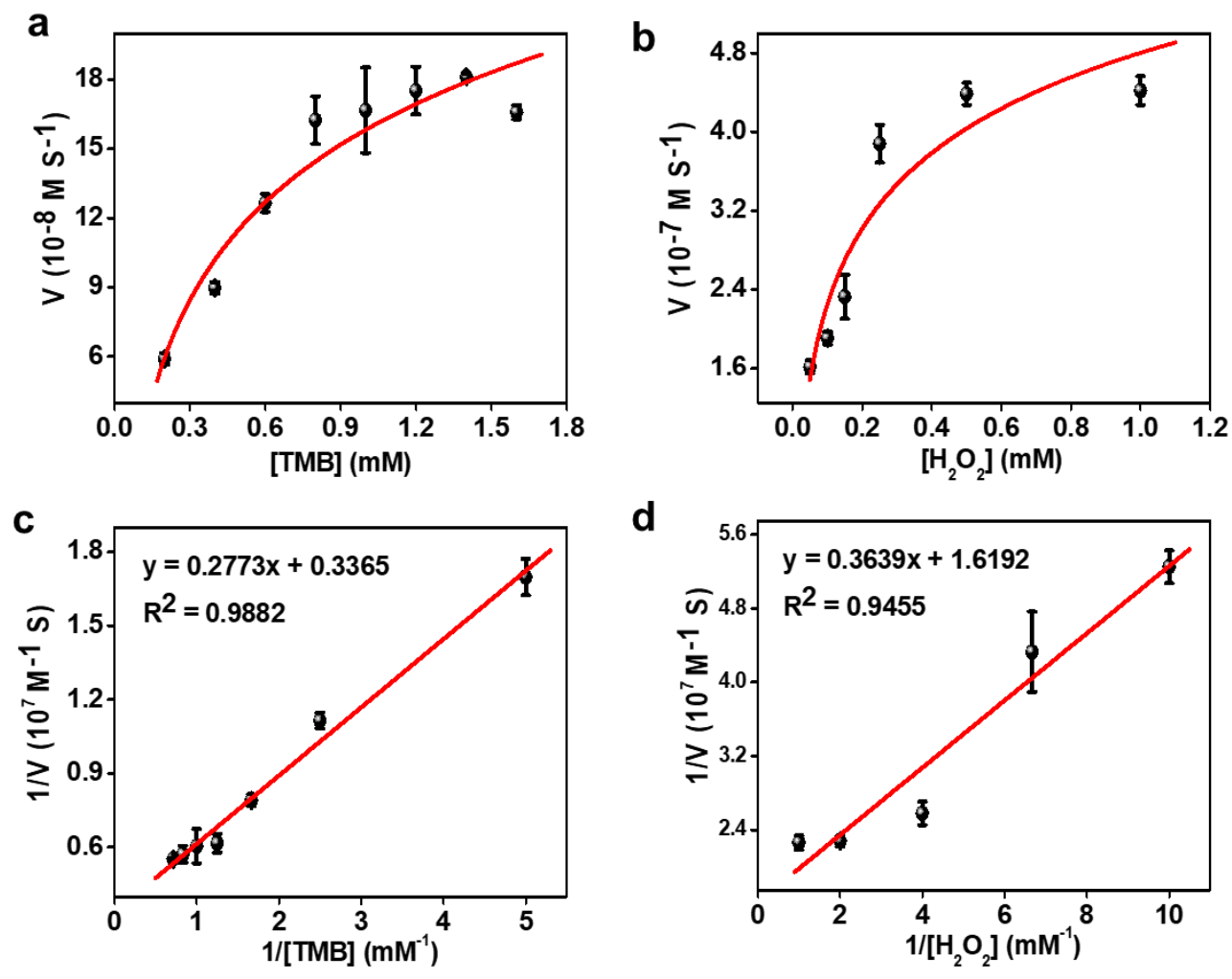

Figure S18. Steady-state kinetic analyses using Michaelis-Menten and Lineweaver-

Burk plot for Fe-MIL-88NH2. a) The concentration of $\mathrm{H}_{2} \mathrm{O}_{2}$ was $0.5 \mathrm{mM}$ and the TMB concentration was varied. b) The concentration of TMB was $1 \mathrm{mM}$ and the $\mathrm{H}_{2} \mathrm{O}_{2}$ concentration was varied. Lineweaver-Burk plots of Fe-MIL- $88 \mathrm{NH}_{2}$ c) TMB as substrate and d) $\mathrm{H}_{2} \mathrm{O}_{2}$ as substrate.

Table S1. The kinetic parameters of Fe-MIL- $88 \mathrm{NH}_{2}$.

\begin{tabular}{cccccc}
\hline Nanozyme & {$[\mathrm{S}][\mathrm{M}]$} & Substrate & $\mathrm{V}_{\max }\left(\mathrm{MS}^{-1}\right)$ & $\mathrm{KM}(\mathrm{M})$ & $\mathrm{K}_{\text {cat }}\left(\mathrm{S}^{-1}\right)$ \\
\hline Fe-MIL- & & $\mathrm{TMB}$ & $3.0 \times 10^{-7}$ & $8.2 \times 10^{-4}$ & $8.6 \times 10^{-3}$ \\
$88 \mathrm{NH}_{2}$ & $3.5 \times 10^{-5}$ & & & & \\
& & $\mathrm{H}_{2} \mathrm{O}_{2}$ & $6.2 \times 10^{-8}$ & $2.2 \times 10^{-4}$ & $1.8 \times 10^{-3}$ \\
\hline
\end{tabular}

[S] represents the concentration of Fe in Fe-MIL-88 $\mathrm{NH}_{2}$, which was obtained by ICP-

MS. $K_{M}$ represents Michaelis-Menten constant. $V_{\max }$ is the maximal reaction rate and 
$K_{\text {cat }}$ is the catalytic constant that equals $V_{\max } /[S] \cdot{ }^{9}$
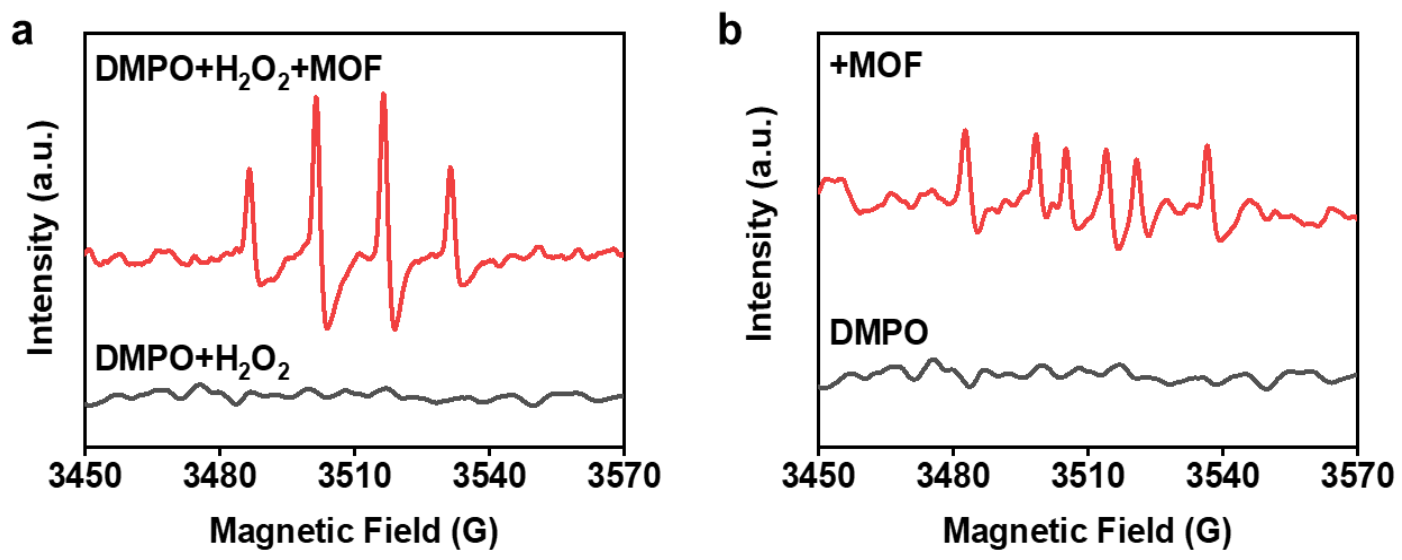

Figure S19. a) EPR spectra of Fe-MIL-88 $\mathrm{NH}_{2}(50 \mu \mathrm{g} / \mathrm{mL})$ with $\mathrm{H}_{2} \mathrm{O}_{2}$ showing the generation of $\bullet \mathrm{OH}$. b) EPR spectra of Fe-MIL- $88 \mathrm{NH}_{2}(50 \mu \mathrm{g} / \mathrm{mL})$ without $\mathrm{H}_{2} \mathrm{O}_{2}$ showing the generation of $\mathrm{O}_{2}{ }^{\circ}$.

The characteristic signal peak in a) demonstrated the generation of $\bullet \mathrm{OH}$ and the characteristic signal peak in b) demonstrated the generation of $\mathrm{O}_{2}{ }^{*-16}$
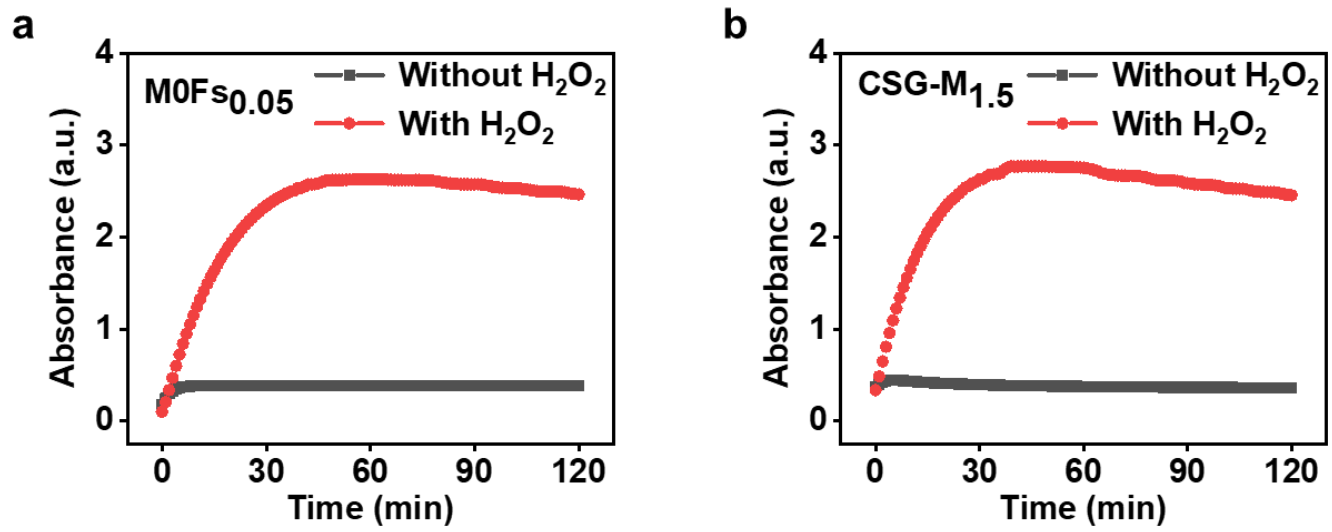

Figure S20. The effect of time on the catalytic reaction of Fe-MIL- $88 \mathrm{NH}_{2}$ and CSG- 

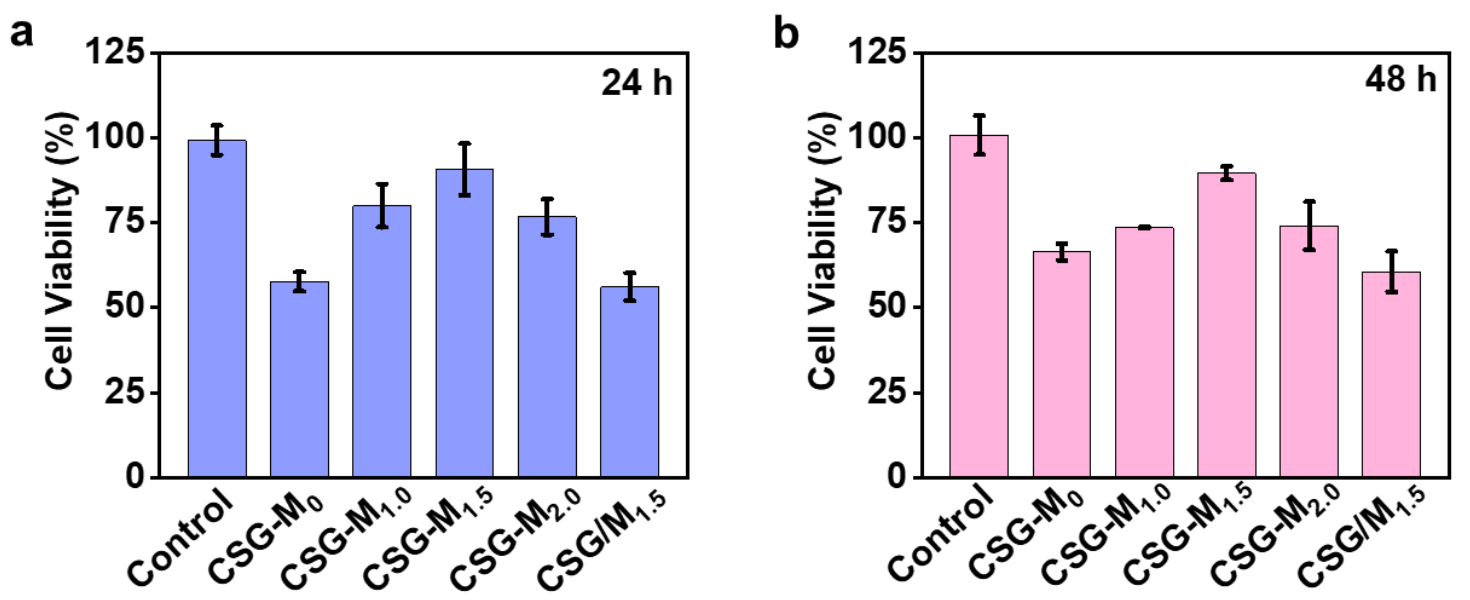

Figure S21. Cell viability of L929 cells after co-cultured with cryogel samples for a)

$24 \mathrm{~h}$ and b) $48 \mathrm{~h}$.

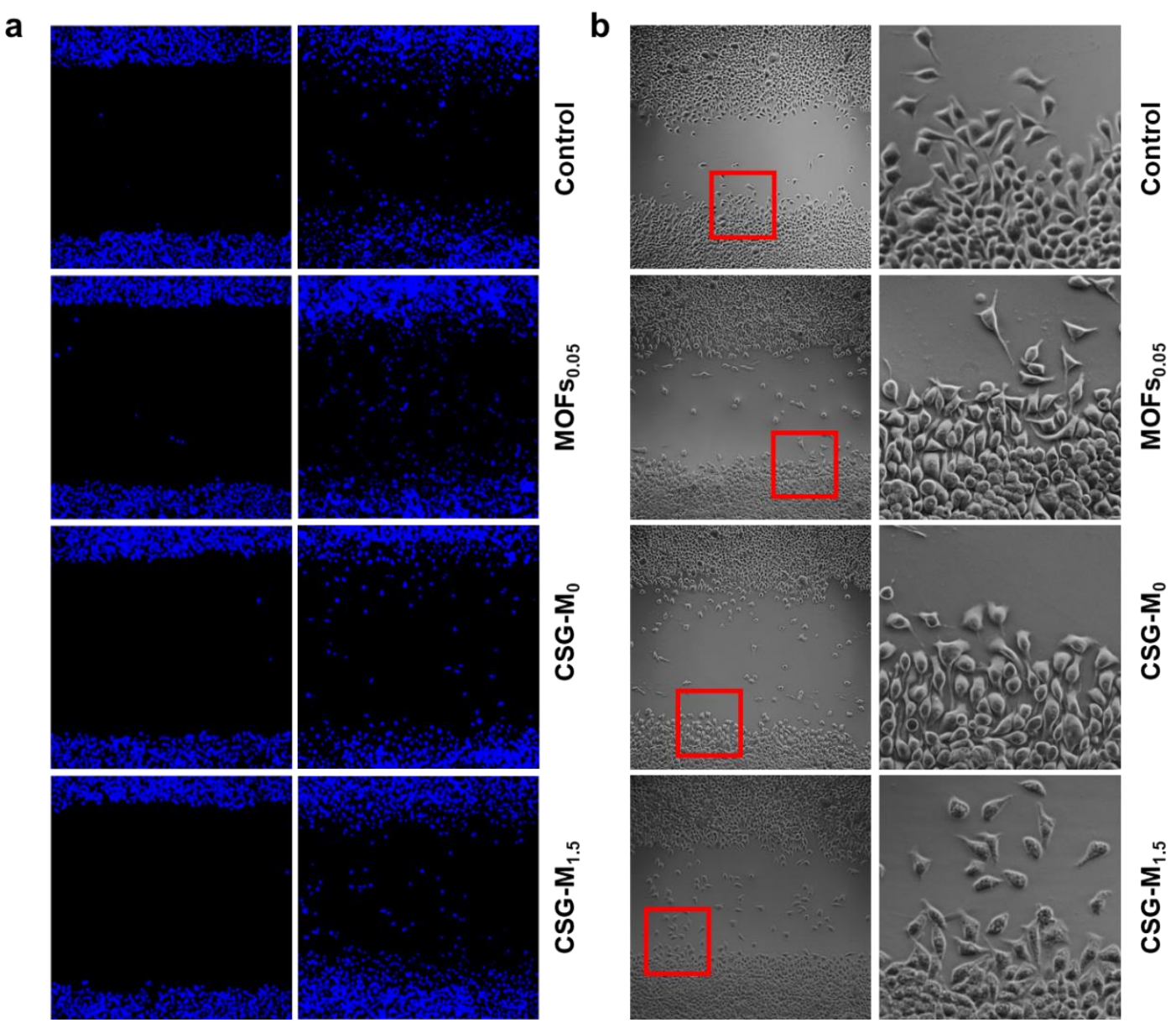

Figure S22. a) Fluorescence images of the cell migration behavior treated with MOFs nanozyme, CSG-Mo, or CSG-M1.5. b) Images of the cell migration behavior treated 
with MOFs nanozyme, CSG-M0, or CSG-M1.5.

a

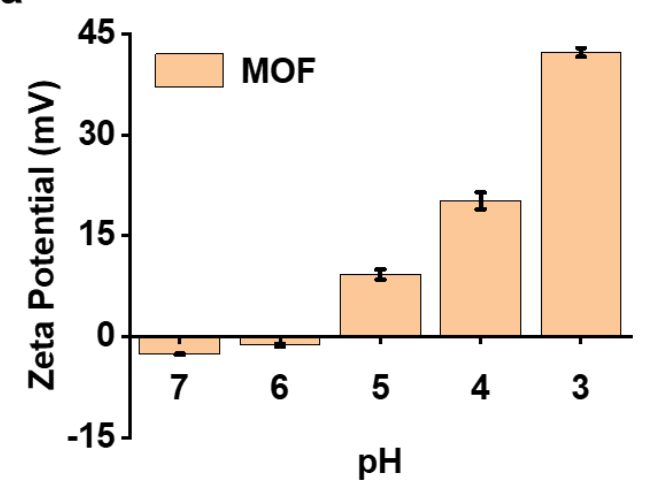

b

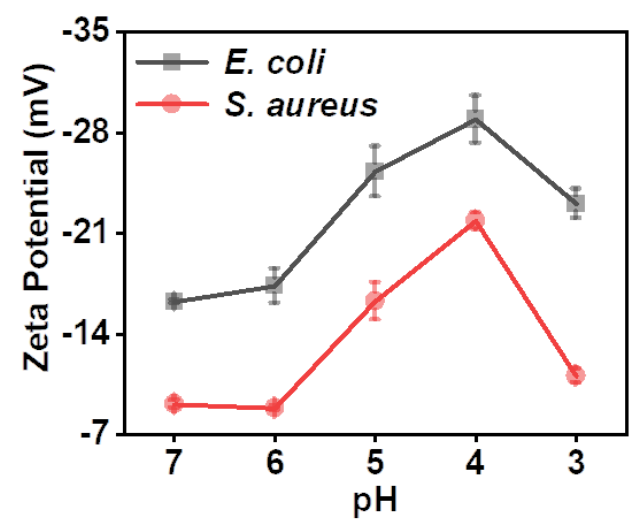

Figure S23. The dependence of zeta potential on $\mathrm{pH}$ value of a) Fe-MIL- $88 \mathrm{NH}_{2}$ and b) S. aureus and E. coli.

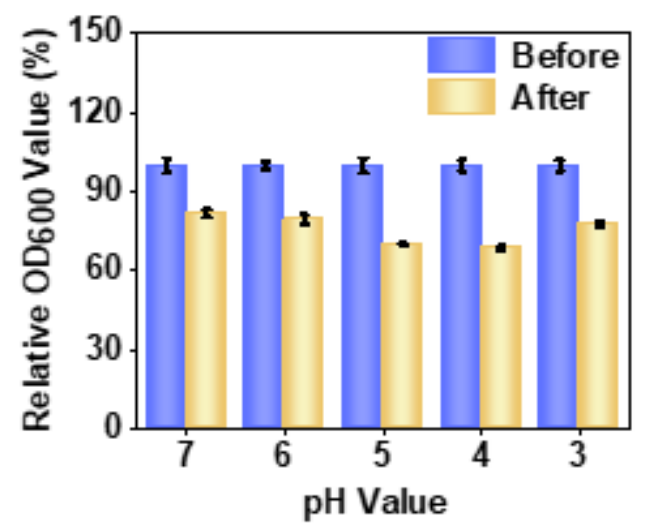

Figure S24. The relative $\mathrm{OD}_{600} \mathrm{~nm}$ value of $S$. aureus solution before or after trapping bacteria under different $\mathrm{pH}$. 
a

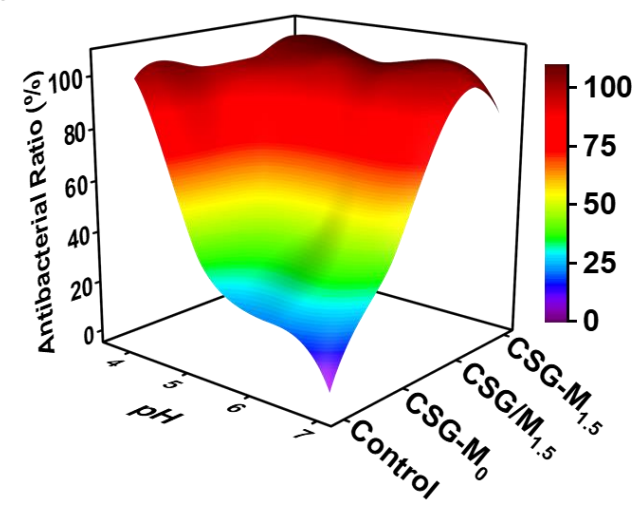

b

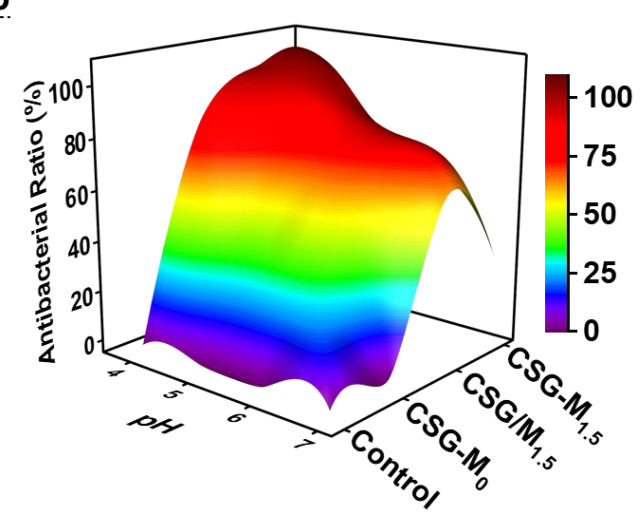

Figure S25. Antibacterial ratios with different treatment a) with $\mathrm{H}_{2} \mathrm{O}_{2}$ and b) without $\mathrm{H}_{2} \mathrm{O}_{2}$.
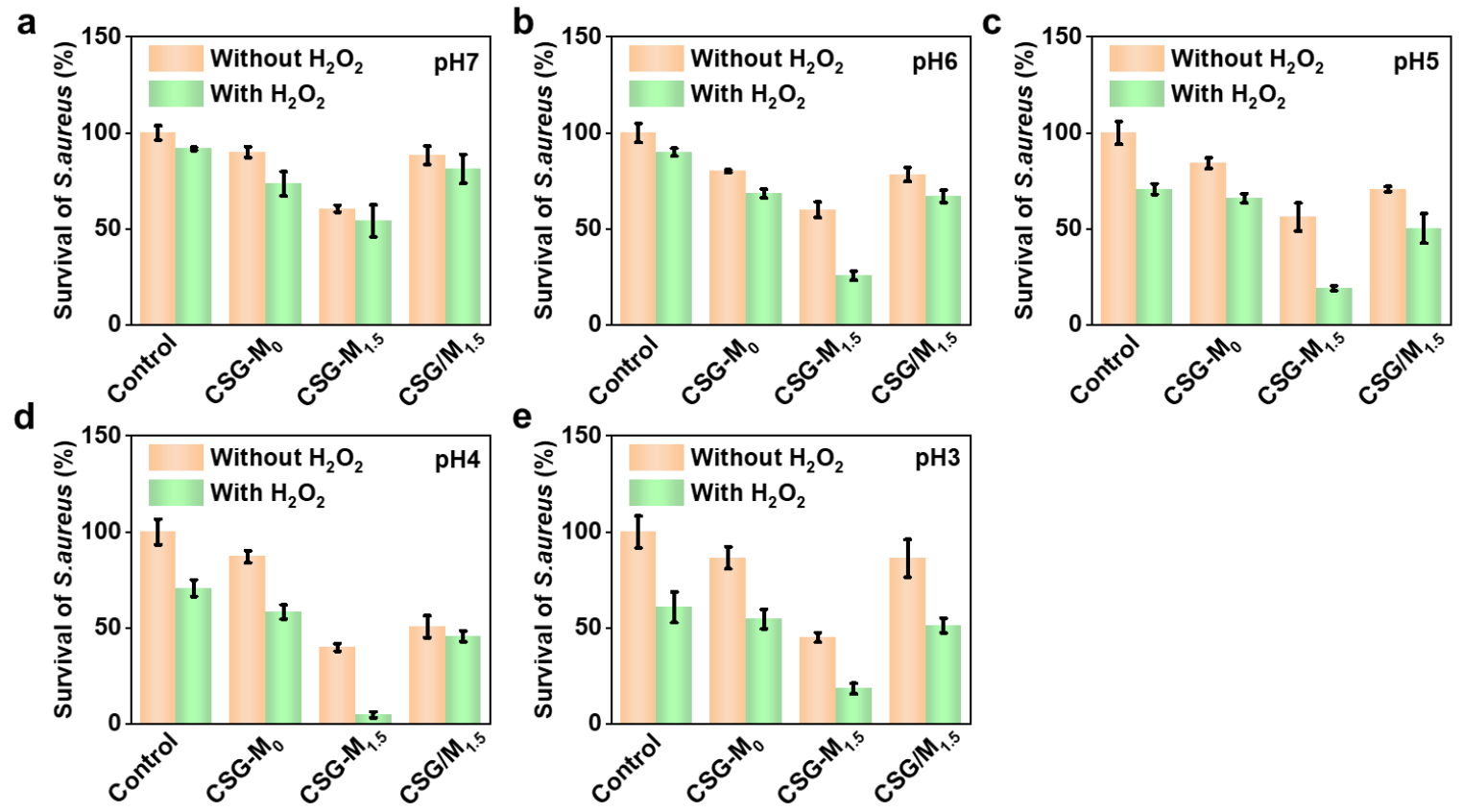

Figure S26. The survival ratios of $S$. aureus treated by cryogel samples under

different $\mathrm{pH}$ in the presence or absence of $\mathrm{H}_{2} \mathrm{O}_{2}$. 
a

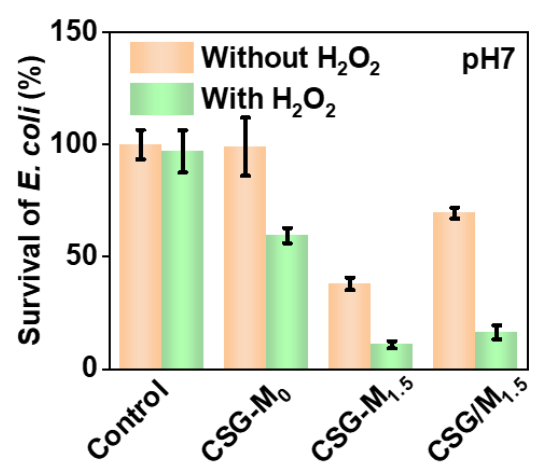

C

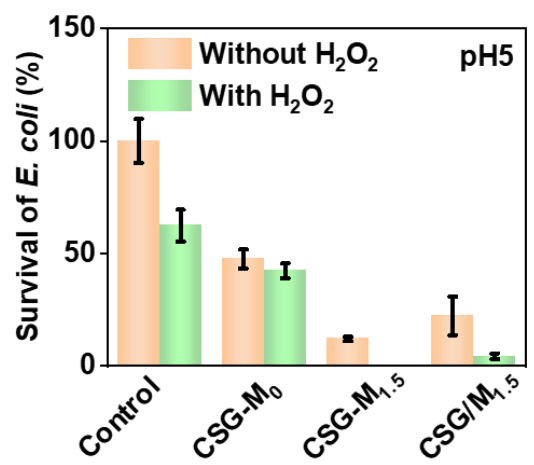

b

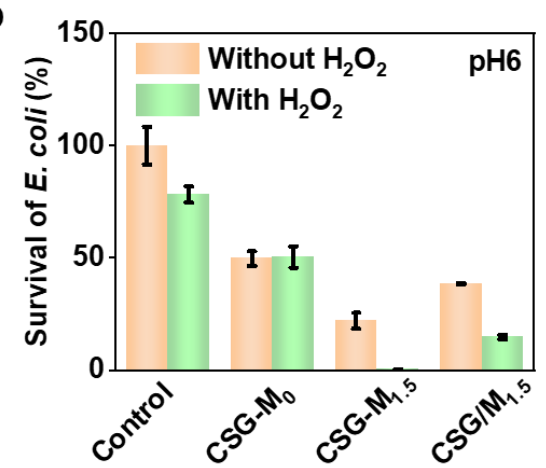

d

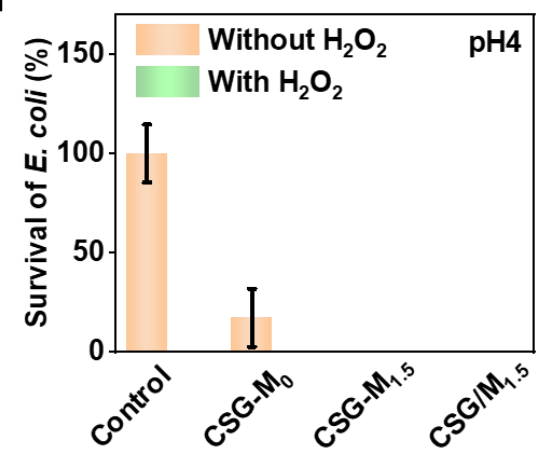

Figure S27. The survival ratios of E. coli treated by CSG-Mx under different $\mathrm{pH}$ in the presence or absence of $\mathrm{H}_{2} \mathrm{O}_{2}$. 


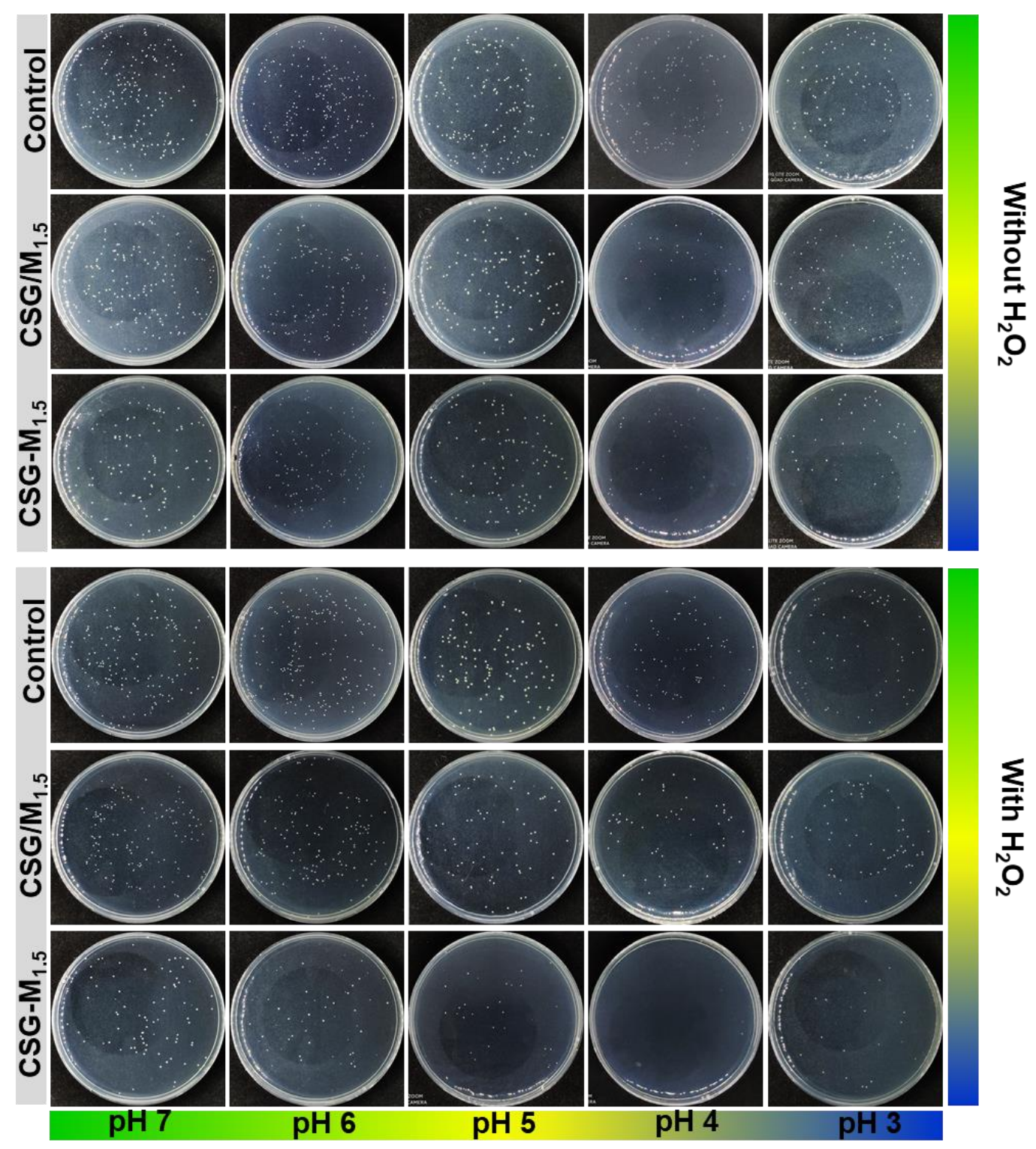

Figure S28. Photographs of bacterial colonies formed by $S$. aureus after treated by CSG/M $\mathrm{M}_{1.5}$ and $\mathrm{CSG}-\mathrm{M}_{1.5}$ with or without $\mathrm{H}_{2} \mathrm{O}_{2}$ under different $\mathrm{pH}$. 


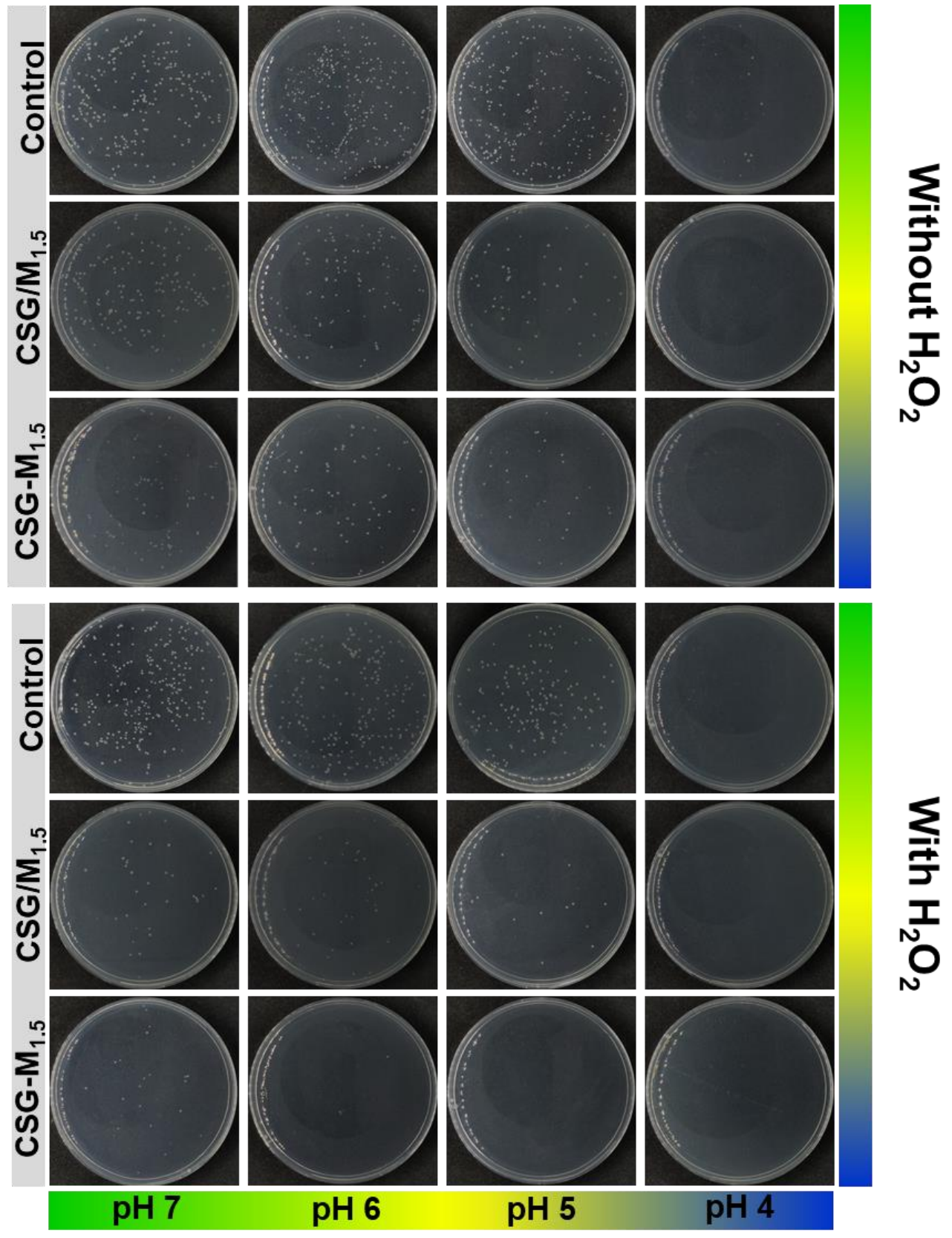

Figure S29. Photographs of bacterial colonies formed by E. coli after treated by CSG/M1.5 and CSG-M 1.5 with or without $\mathrm{H}_{2} \mathrm{O}_{2}$ under different $\mathrm{pH}$. 


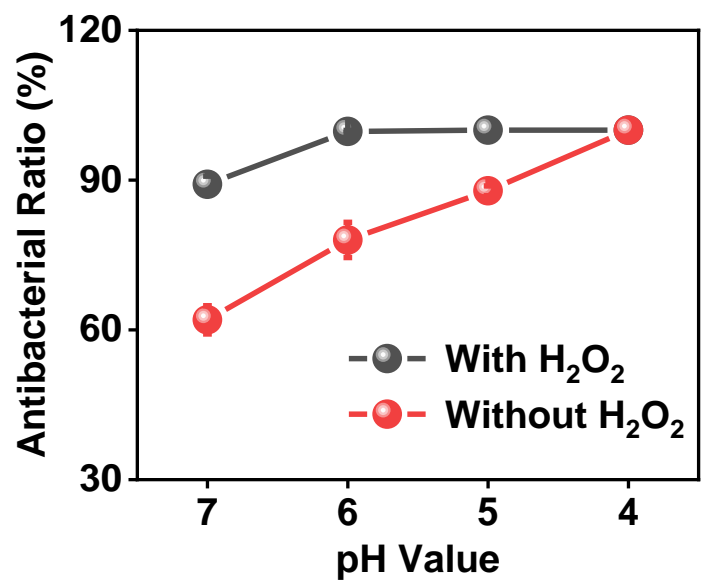

Figure S30. The effect of $\mathrm{pH}$ on anti $E$. coli of CSG-M1.5.

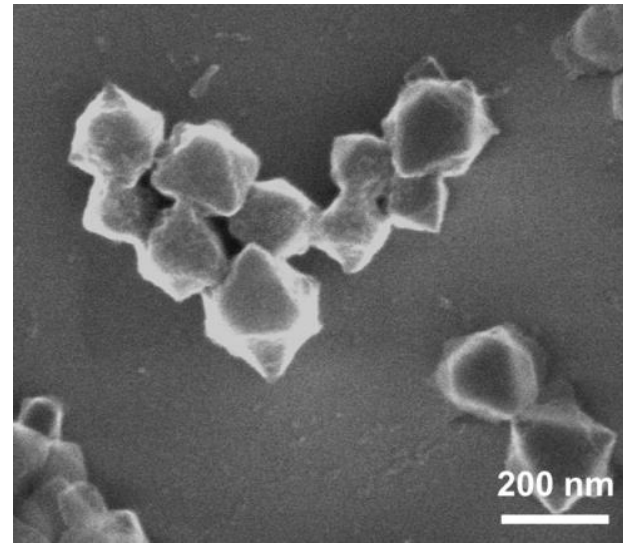

Figure S31. The SEM image of Fe-MIL-88 $\mathrm{NH}_{2}$ released from CSG-M1.5. 

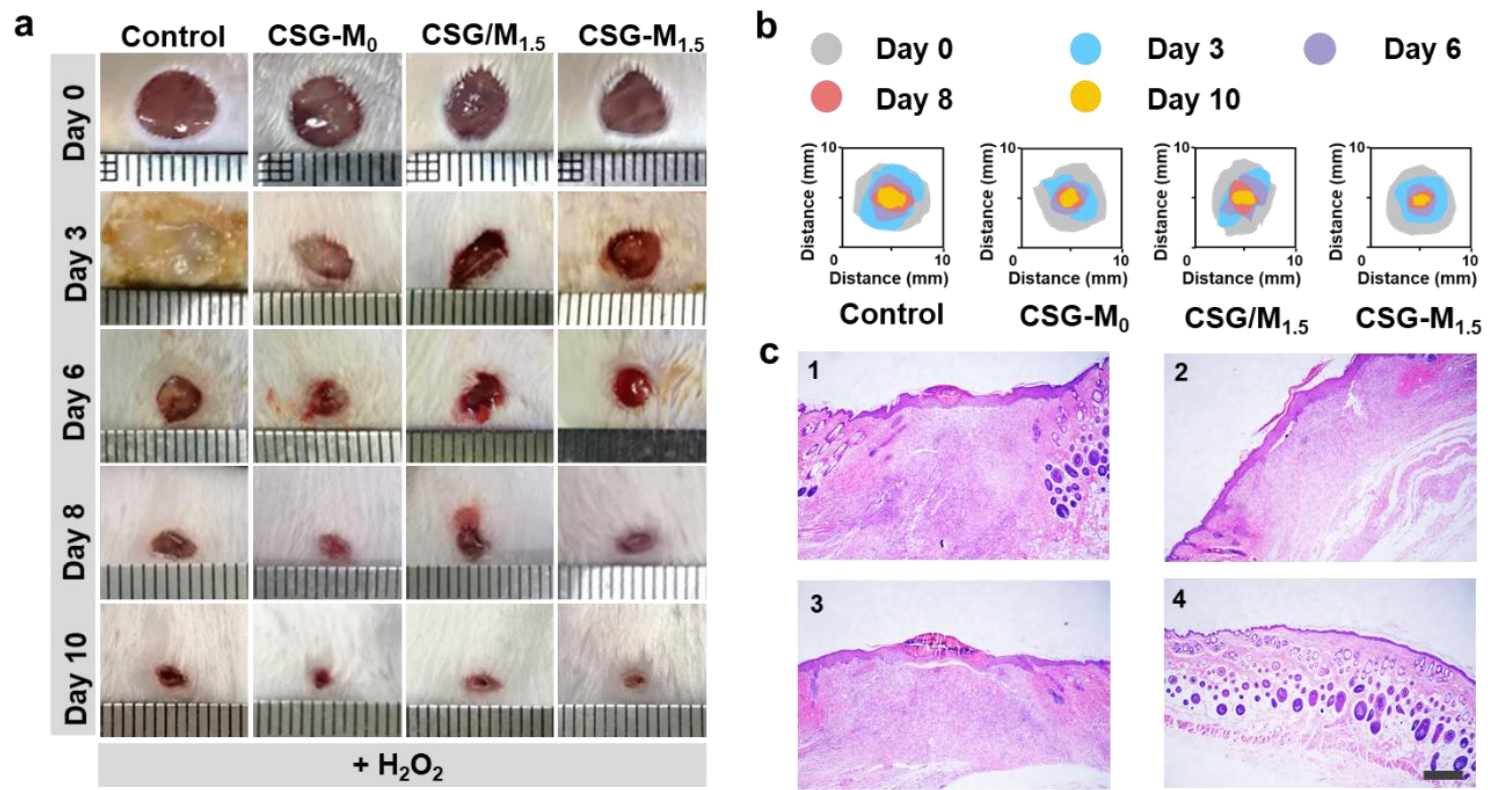

Figure S32. a) The representative photographs of the wound healing process of mice treated by control, CSG-M0, CSG/M1.5, and CSG-M1.5 with $\mathrm{H}_{2} \mathrm{O}_{2}(100 \mu \mathrm{M})$. b) Traces of wound healing during 10 days for each treatment. c) H\&E staining of the skin tissues harvested from mice after 10 days treatment ( 1 treated by $20 \mu \mathrm{L}$ of $100 \mu \mathrm{M}$ $\mathrm{H}_{2} \mathrm{O}_{2} ; 2$ treated by CSG-M $\mathrm{M}_{0}$ and $20 \mu \mathrm{L}$ of $100 \mu \mathrm{M} \mathrm{H}_{2} \mathrm{O}_{2} ; 3$ treated by CSG/M 1.5 and $20 \mu \mathrm{L}$ of $100 \mu \mathrm{M} \mathrm{H}_{2} \mathrm{O}_{2}$; 4 treated by CSG-M1.5 and $20 \mu \mathrm{L}$ of $100 \mu \mathrm{M} \mathrm{H}_{2} \mathrm{O}_{2}$ ). Scale bars: $400 \mu \mathrm{m}$. 
a

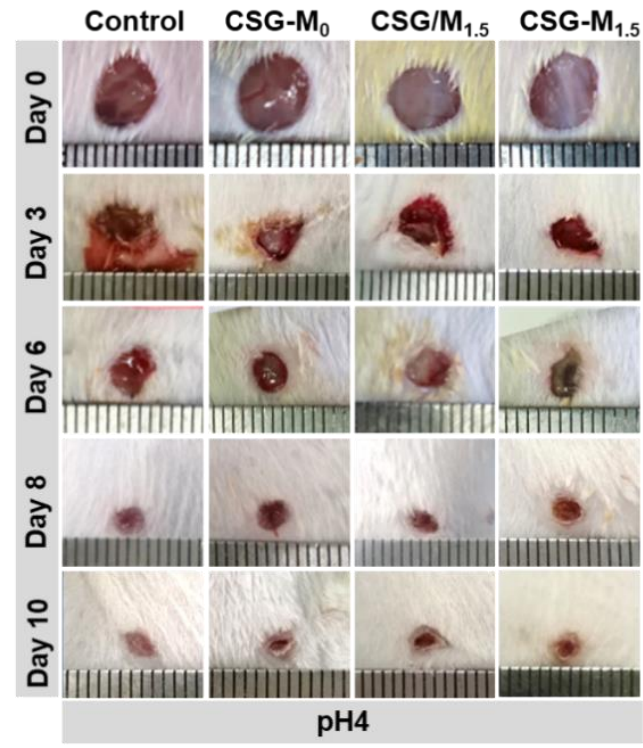

b

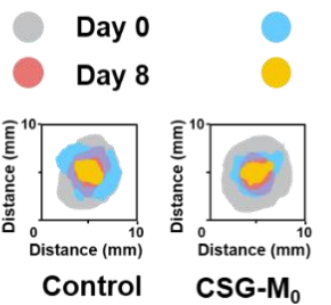

C

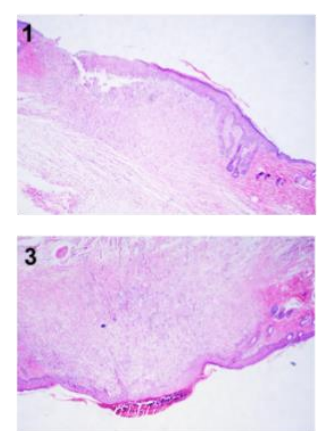

Day 3

Day 10

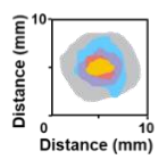

CSG/M $/ M_{15} \quad$ CSG-M
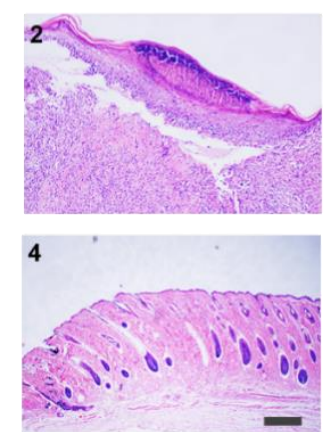

Figure S33. a) The representative photographs of the wound healing process of mice treated by control, CSG-M0, CSG/M1.5, and CSG-M1.5 at pH4 (adjusted by $0.1 \mathrm{M}$

NaAc buffer). b) Traces of wound healing during 10 days for each treatment. c) H\&E staining of the skin tissues slices harvested from mice after 10 days treatment (1 treated by $20 \mu \mathrm{L}$ of $0.1 \mathrm{M} \mathrm{NaAc}$ buffer; 2 treated by CSG-Mo and $20 \mu \mathrm{L}$ of $0.1 \mathrm{M}$ NaAc buffer; 3 treated by CSG/M1.5 and $20 \mu \mathrm{L}$ of $0.1 \mathrm{M} \mathrm{NaAc}$ buffer; 4 treated by CSG-M1.5 and $20 \mu \mathrm{L}$ of $0.1 \mathrm{M} \mathrm{NaAc}$ buffer). Scale bars: $400 \mu \mathrm{m}$. 


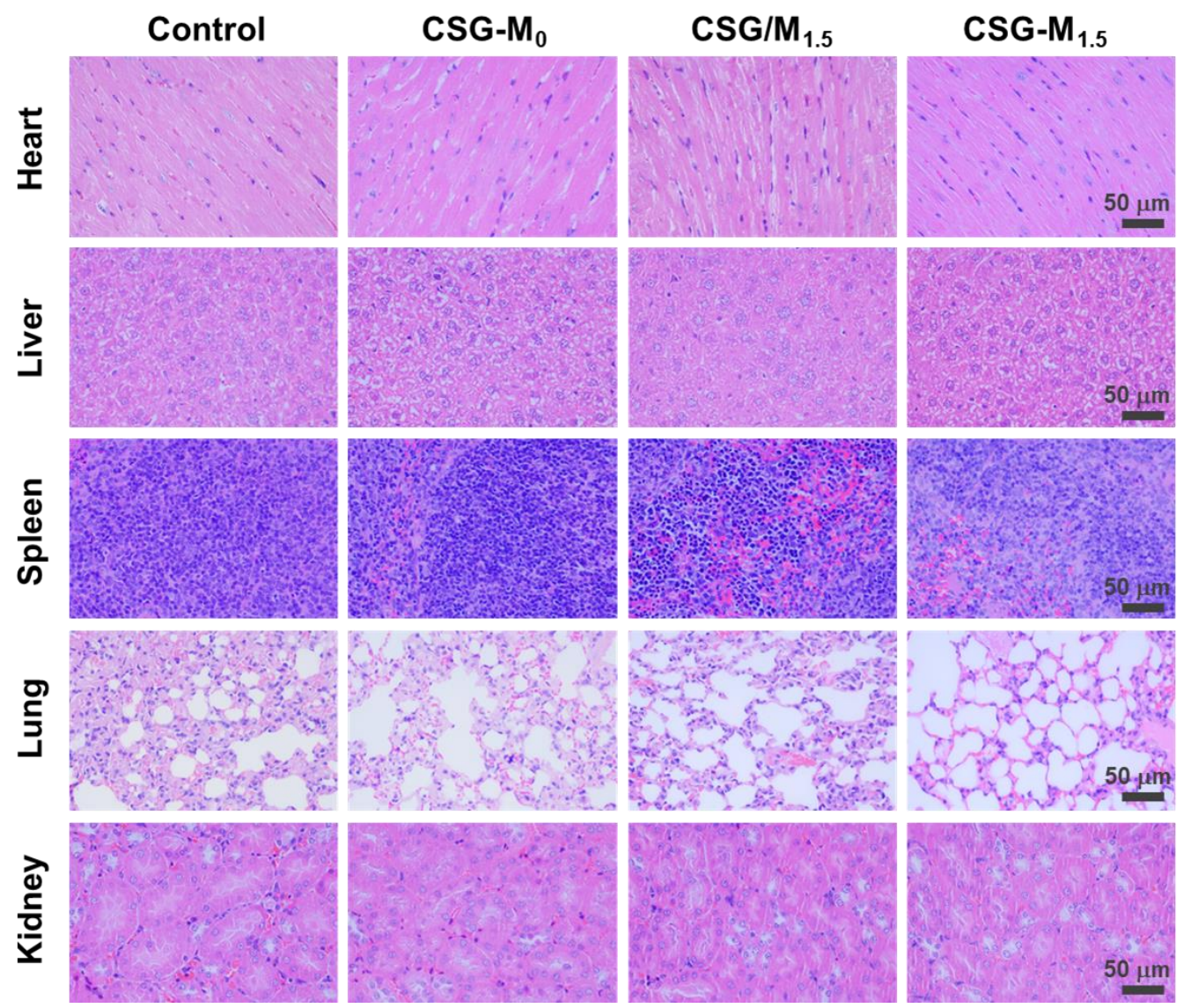

Figure S34. H\&E staining of the heart, liver, spleen, lung, and kidney tissue slices harvested from mice after 10 days treatment (control). 


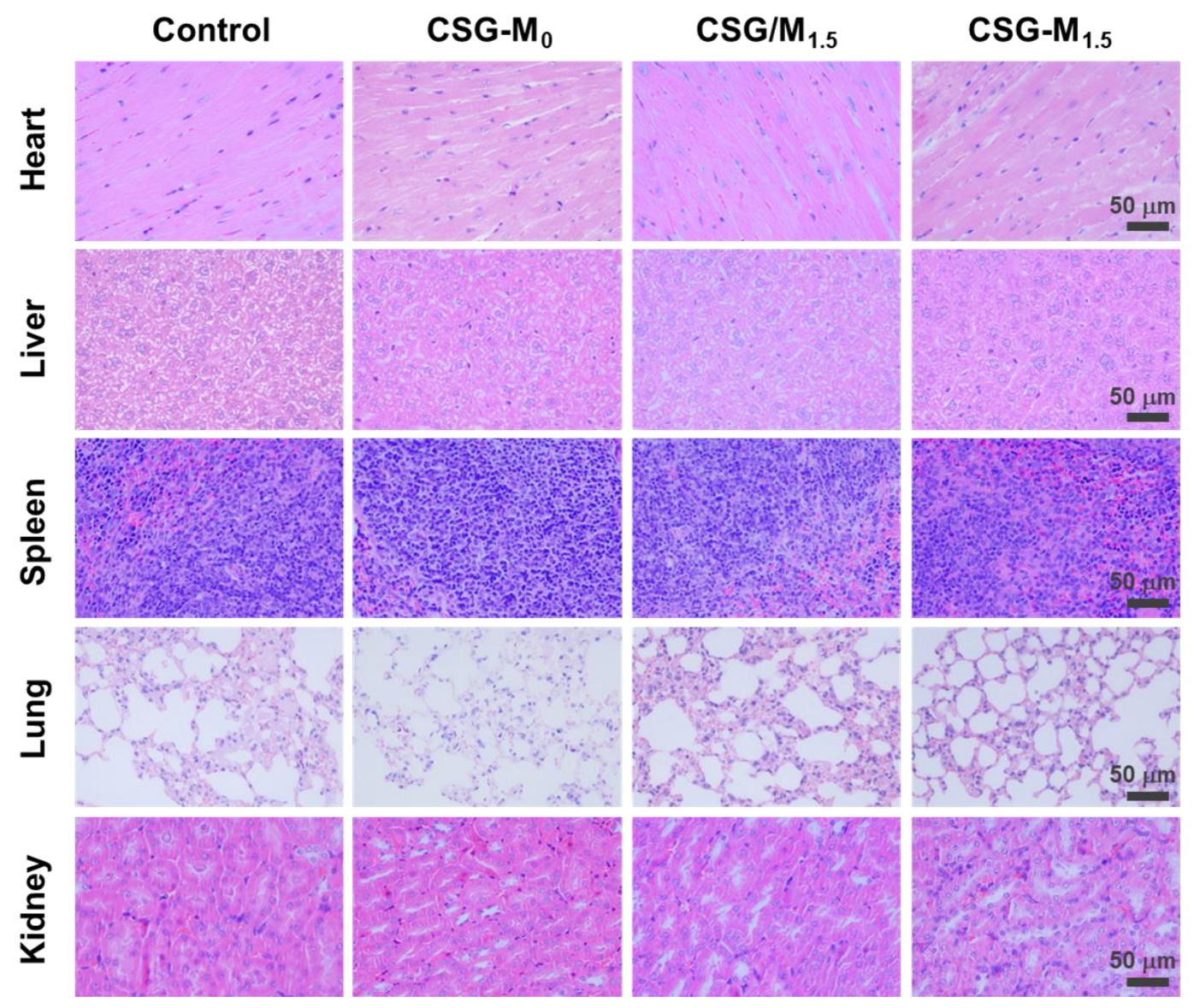

Figure S35. H\&E staining of the heart, liver, spleen, lung, and kidney tissue slices harvested from mice after 10 days treatment (with $\mathrm{H}_{2} \mathrm{O}_{2}$ ). 


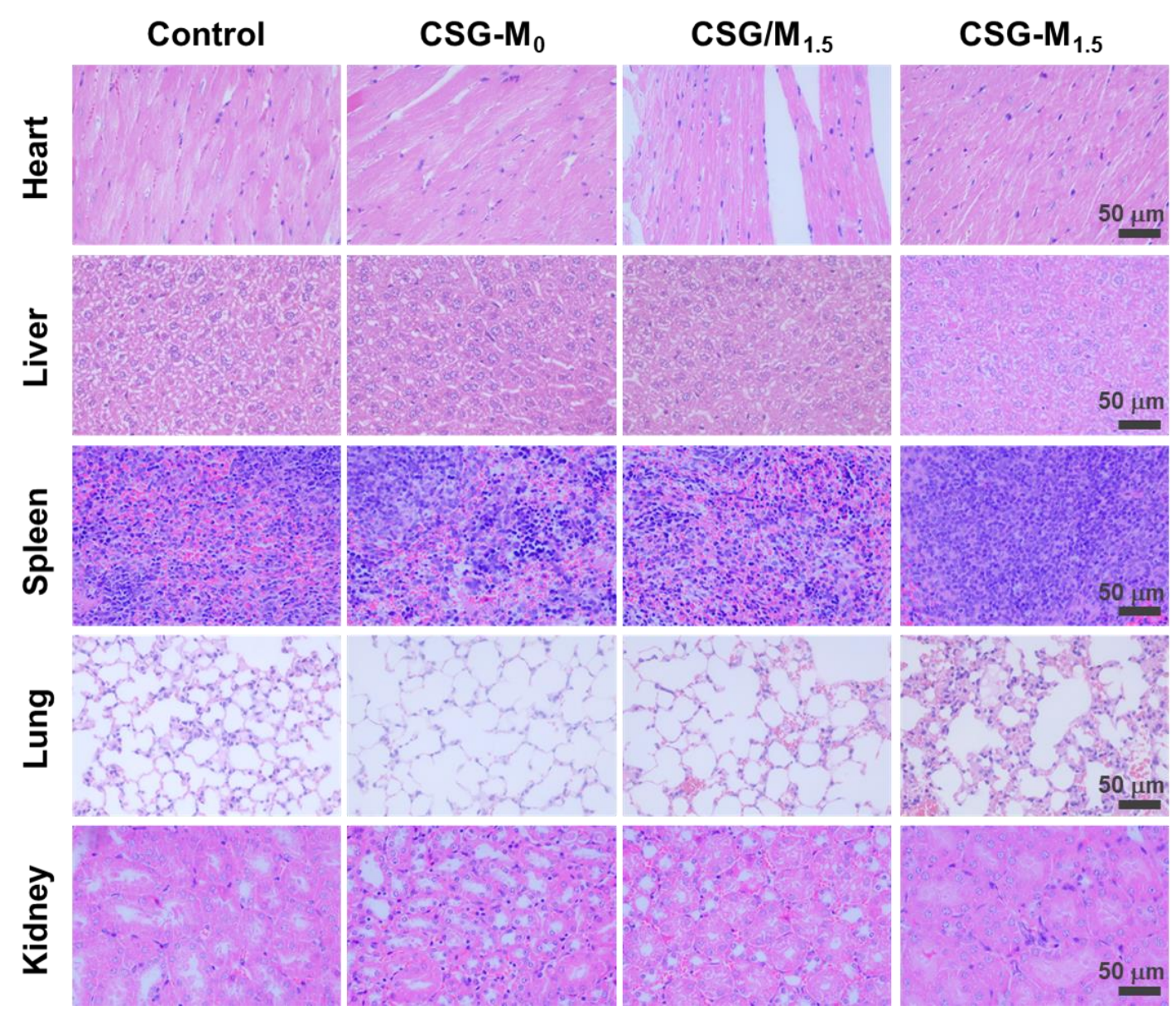

Figure S36. H\&E staining of the heart, liver, spleen, lung, and kidney tissue slices

harvested from mice after 10 days treatment (without $\mathrm{H}_{2} \mathrm{O}_{2}$, and the $\mathrm{pH}$ adjusted to 4 by $0.1 \mathrm{M} \mathrm{NaAc}$ buffer). 


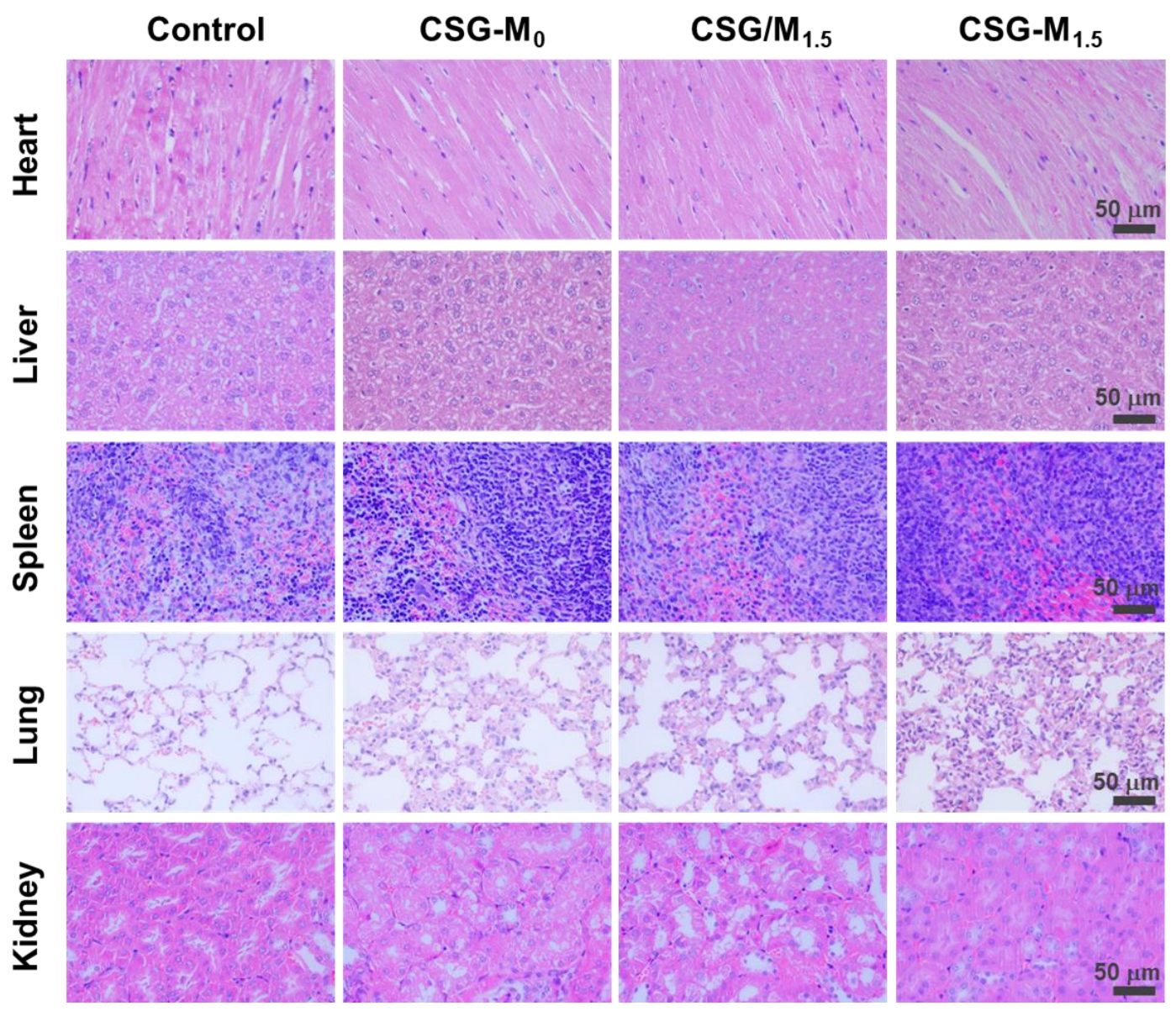

Figure S37. H\&E staining of the heart, liver, spleen, lung, and kidney tissue slices harvested from mice after 10 days treatment (with $\mathrm{H}_{2} \mathrm{O}_{2}$, and the $\mathrm{pH}$ adjusted to 4 by 0.1 M NaAc buffer).

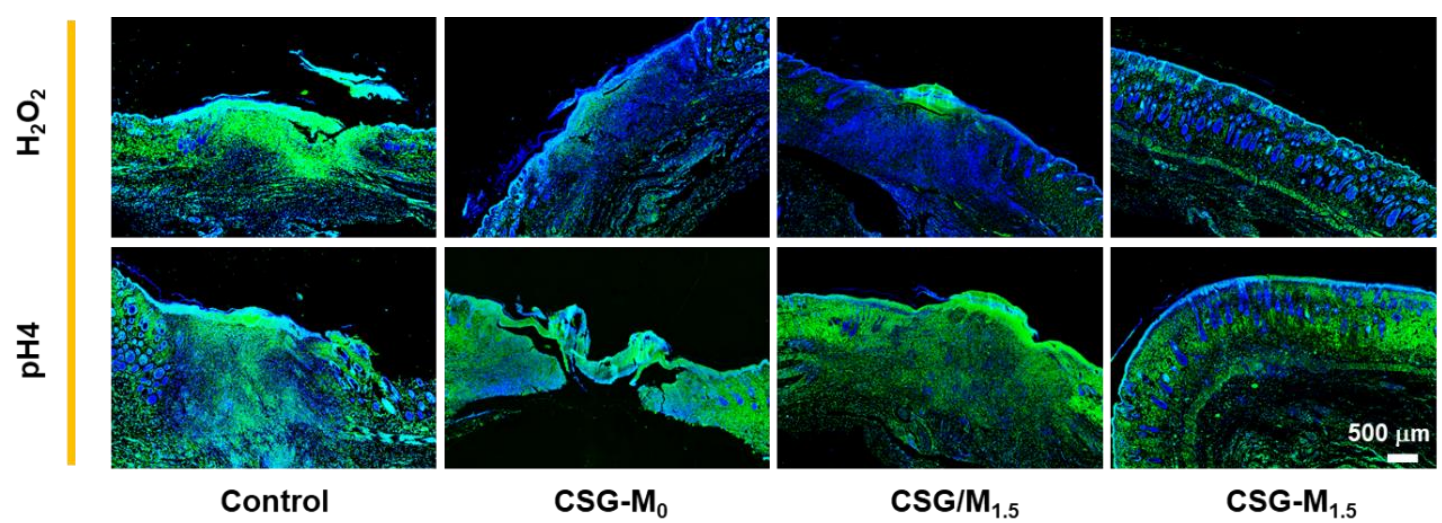

Figure S38. Immunofluorescence staining of IL-6 in wound bed at day10. 


\section{References}

1. Chen, T.; Zou, H.; Wu, X.; Liu, C.; Bo, S.; Zheng, L.; Yang, G. Nanozymatic Antioxidant System Based on $\mathrm{MoS}_{2}$ Nanosheets. ACS Appl. Mater. Interfaces 2018, 10, 12453-12462.

2. Aleksandra, N.; Katarzyna, K.; Krzysztof, P.; Łukasz, S.; Grazyna, G. Curdlan-Based Hydrogels for Potential Application as Dressings for Promotion of Skin Wound Healing-Preliminary in Vitro Studies. Materials 2021, 14, 2344-2360.

3. Alireza, J.; Mohammad, T. K.; Hassan, A.; Zohreh, M. M.; Armaghan, M. Fabrication of Heparinized Nano ZnO/Poly(vinylalcohol)/Carboxymethyl Cellulose Bionanocomposite Hydrogels Using Artificial Neural Network for Wound Dressing Application. J. Ind. Eng. Chem. 2019, 25, 253-263.

4. Hassan, N.; Rasul, R.; Hamed H.; Hossein, S. K. Antibiotic Loaded Carboxymethylcellulose/MCM-41 Nanocomposite Hydrogel Films as Potential Wound Dressing. Int. J. Biol. Macromol. 2016, 85, 327-334.

5. Mehdi, Y.; Hassan, N.; Soroush, B. Preparation and Properties of Carboxymethyl Cellulose/Layered Double Hydroxide Bionanocomposite Films. Carbohydr. Polym. 2014, 108, 83-90.

6. Shi, L.; Liu, X.; Wang, W.; Jiang, L.; Wang, S. A Self-Pumping Dressing for Draining Excessive Biofluid Around Wounds. Adv. Mater. 2018, 31, 18041871804196.

7. Zhao, X.; Guo, B.; Wu, H.; Liang, Y.; Peter, X. M. Injectable Antibacterial 
Conductive Nanocomposite Cryogels with Rapid Shape Recovery for Noncompressible Hemorrhage and Wound Healing. Nat. Commun. 2018, 9, 2784-3801.

8. Tao, Y.; Ju, E.; Ren, J.; Qu, X. Bifunctionalized Mesoporous Silica-Supported Gold Nanoparticles: Intrinsic Oxidase and Peroxidase Catalytic Activities for Antibacterial Applications. Adv. Mater. 2014, 27, 1097-1105.

9. Xu, W.; Jiao, L.; Yan, H.; Wu, Y.; Chen, L.; Gu, W.; Du, D.; Lin, Y.; Zhu, C. Glucose Oxidase-Integrated Metal-Organic Framework Hybrids as Biomimetic Cascade Nanozymes for Ultrasensitive Glucose Biosensing. ACS Appl. Mater. Interfaces 2019, 11, 22096-22101.

10. Sang, Y.; Li, W.; Liu, H.; Zhang, L.; Wang, H.; Liu, Z.; Ren, J.; Qu, X. Construction of Nanozyme-Hydrogel for Enhanced Capture and Elimination of Bacteria. Adv. Funct. Mater. 2019, 29, 1900518-1900528.

11. Wang, S.; Zheng, H.; Zhou, L.; Cheng, F.; Liu, Z.; Zhang, H.; Wang, L.; Zhang, Q. Nanoenzyme-Reinforced Injectable Hydrogel for Healing Diabetic Wounds Infected with Multidrug Resistant Bacteria. Nano Lett. 2020, 20, 5149-5158.

12. Niu, G.; Zhang, H.; Song, L.; Cui, X.; Cao, H.; Zheng, Y.; Zhu, S.; Yang, Z.; Yang, H. Thiol/Acrylate-Modified PEO-PPO-PEO Triblocks Used as Reactive and Thermosensitive Copolymers. Biomacromolecules 2008, 9, $2621-2628$.

13. Li, Y.; Wang, D.; Wen, J.; Liu, J.; Zhang, D.; Li, J.; Chu, H. Ultra-Stretchable, 
Variable Modulus, Shape Memory Multipurpose Low Hysteresis Hydrogel Derived from Solvent-Induced Dynamic Micelle Sea-Island Structure. $A d v$. Funct. Mater. 2021, 31, 2011259-2011271.

14. Ping, Y.; Liu, C.; Zhang, Z.; Liu, K. L.; Chen, J.; Li, J. Chitosan-Graft-(PEI$\beta$-Cyclodextrin) Copolymers and Their Supramolecular PEGylation for DNA and siRNA Delivery. Biomaterials 2011, 32, 8328-834.

15. Jin, L. Y.; Dong, Y. M.; Wu, X. M.; Cao, G. X.; Wang, G. L. Versatile and Amplified Biosensing through Enzymatic Cascade Reaction by Coupling Alkaline Phosphatase in Situ Generation of Photoresponsive Nanozyme. Anal. Chem. 2015, 87, 10429-10437.

16. Cheng, M.; Ma, W.; Li, J.; Huang, Y.; Zhao, J.; Wen, Y. X.; Xu, Y. VisibleLight-Assisted Degradation of Dye Pollutants over Fe(III)-Loaded Resin in the Presence of $\mathrm{H}_{2} \mathrm{O}_{2}$ at Neutral pH Values. Environ. Sci. Technol. 2004, 38, $1569-1575$. 